\title{
Pablo, el antisistema
}

La insatisfacción con el método histórico crítico de los estudios bíblicos durante las últimas generaciones ha hecho que surjan y proliferen perspectivas innovadoras. La Third Quest abrió nuevos horizontes para el estudio del Jesús Histórico, horizontes que también se han extendido a los estudios de la figura de Pablo. Anteriormente, se consideraba al apóstol como un personaje paradigmático que experimentó una conversión del judaísmo al cristianismo. Pablo era el gran teólogo cristiano que articuló la difícil transición de la justificación por las obras a la justificación por la fe. Esta visión introspectiva agustiniana y luterana sobre el apóstol de los gentiles ha sido cuestionada en las últimas décadas por la denominada "new perspective" 1 de los estudios paulinos ${ }^{2}$. Los representantes de este grupo son mayoritariamente de lengua inglesa. Esta nueva perspectiva quiere ofrecer el mayor cambio de paradigma en los estudios paulinos de todos los tiempos. Pretende el desmontaje de la construcción teológica luterana (alemana) de Pablo que lo presenta como héroe de la justificación por la fe.

Sin embargo, la nueva perspectiva no ha supuesto ese gran cambio de paradigma anunciado, ya que ha perpetuado la perspectiva teológica an-

${ }^{1}$ La expresión hace referencia al título de un artículo de J.D.G. DunN, The New Perspective on Paul, en: Bulletin of the John Rylands Library 65 (1983) 95-122;Véase J.D. DunN, The New Perspective on Paul. Collected Essays (WUNT 185), Mohr Siebeck, Tübingen 2005, 89-110.

2 Stephen Westerholm, Perspectives Old and New on Paul. The „Lutheran“ Paul and His Critics, WM.B. Eerdmns, Grand Rapids-Cambridge 2004; M. Bachmann (Hrsg.), Lutherische und Neue Paulusperspektive. Beiträge zu einem Schlüsselproblem der gegenwärtige exegetischen Diskussion (WUNT 182), Mohr Siebeck, Tübingen 2005; A.J.M. Wedderburn, Eine neuere Paulusperspektive?, en: E.-M. Becker - P. Pilhofer (Hrsg.), Biographie und Persönlichkeit des Paulus (WUNT 187), Mohr Siebeck, Tübingen 2005, 46-64; B.W. Longenecker, On Critique the ,New Perspective' on Paul: A Case Study, en: ZNW 96 (2005) 263-271. Existe una página Web dedicada a la nueva perspectiva en los estudios paulinos, con posibilidad de consultar muchos artículos: www.thepaulpage.com 
terior, según la cual Pablo estaba centrado fundamentalmente en su nueva religión, el cristianismo, frente a su anterior religión judía, tal y como postula una de las citas más mencionadas de esta nueva orientación: "In short, that is what Paul finds wrong in Judaism: it is not Christianity"3. Los temas de la ley, el pecado, la justificación y la fe permanecen en el centro de la discusión entre los seguidores de la nueva perspectiva y los teólogos luteranos. La nueva visión, sin embargo, ignora el contexto imperial romano donde se desarrolló la misión paulina.

Ante esta desazón, un grupo de estudiosos, mayoritariamente americano $^{4}$, ha anunciado un verdadero cambio de modelo en los estudios paulinos. La interpretación que propone es, en cierto sentido, una continuación de la denominada Third Quest aplicada en la investigación del Jesús histórico: tras la importancia dada en los últimos decenios al tema del imperio en los estudios del Jesús histórico, este grupo de autores interpreta al apóstol Pablo desde el contexto y la perspectiva del imperio romano. El mundo romano era el ambiente en que surgieron las comunidades paulinas. Los seguidores de esta visión pertenecen a un grupo de trabajo de la Society of Biblical Literature, denominado "Politics Group". Uno de sus mayores exponentes es Richard A. Horsley, quien se ha encargado de editar hasta el presente las contribuciones y estudios del grupos.

Hasta épocas recientes no se otorgó la debida importancia al tema del imperio romano en los estudios de NT. Primero se aplicó la cuestión del imperio a los estudios del Jesús Histórico y ahora llega su turno al apóstol. Estos investigadores de Pablo están respondiendo, en parte, a los recientes avances en los estudios de la historia antigua, analizando la ideología del imperio, la economía explotadora o la naturaleza parásita de la

\footnotetext{
${ }^{3}$ E.P. SANDERs, Paul and Palestinian Judaism: A Comparison of Patterns of Religion, Fortress, Philadelphia 1977, 552.

${ }^{4} \mathrm{La}$ recepción de las ideas y de la perspectiva que proponen es escasa fuera del ámbito americano. En el mundo alemán cabe destacar algún artículo dedicado al tema: Wiard Popkes, Zum Thema "Anti-imperiale Deutung neutestamentlicher Schriften", en: ThL 127 (2002) 850-862; Idem, Philipper 4,4-7. Aussagen und situativer Hintergrund, en: NTS 50 (2004) $246-256$

5 Richard A. HoRsley (ed.), Paul and Empire. Religion and Power in Roman Imperial Society, Trinity Press International, Harrisburg, Pennsylvania 1997; Richard A. Horsley (ed.), Paul and Politics. Ekklesia, Israel, Imperium, Interpretation. Essays in Honor of Krister Stendahl, Trinity Press International, Harrisburg, Pennsylvania 2000; Richard A. Horsley (ed.), Paul and the Roman Imperial Order, Trinity Press International, Harrisburg, Pennsylvania 2004. Otras contribuciones recientes en este ámbito: J.D. Crossan, Paul and Rome. The Challenge of a Just World Order, en: UnSemQuartRev 59 (2005) 6-20; P.T. Kroeker, Whither Messianic Ethics? Paul as Political Theorist, en: Journal of the Society of Christian Ethics 25 (2005) 37-58.
} 
globalización económica bajo el sistema globalizado de los romanos. No obstante, tampoco se puede decir que esta propuesta sea novedosa ${ }^{6}$. Ya Adolf Deismann ${ }^{7}$ se fijó en los paralelismos con el imperio: a no ser que Pablo y sus colaboradores fueran ciegos, debemos suponer que los conceptos e imágenes con los que los primeros cristianos se confrontaban cada día formaban el trasfondo frente al que se formuló el mensaje cristiano: el NT es un libro de la época imperial. Los cristianos aplicaron a Jesús términos que procedían y se utilizaban para el culto al emperador. Pero tras la segunda Guerra Mundial, la relación entre el cristianismo y su matriz judía copó el centro de atención de los estudiosos del NT. En los últimos años, sin embargo, hemos asistido a un interés renovado por el tema del cristianismo y el imperio romano y, en concreto, por el culto al emperador ${ }^{8}$. Sin lugar a dudas que aquí también han influido factores sociales contemporáneos que explican el resurgir de los estudios por esta temática, como puede ser el aumento de conciencia crítica respecto a las operaciones globalizadas, las cuales pueden ser entendidas como una versión moderna del imperio romano?.

6 Nietzsche ya proponía semejantes ideas, cf. Jan Rehmann, Nietzsche, Paul, and the Subversion of Empire, en: Union Seminary Quarterly Review 59 (2005) 147-161, "He was the Jewish intellectual capable of "guessing, how one could unite all who lay at the bottom, all who were secretly rebellious, the whole inheritance of anarchistic agitation in the Empire, into a tremendous power" (p. 157). Contra el pluralismo romano desde arriba, Pablo ofrece una imaginería contra el imperio desde abajo, un "universalismo" subversivo que supera fronteras. Cf. Jacob Taubes, Die politische Theologie des Paulus, Wilhelm Fink Verlag, München $2003^{3}, 106-131$.

7 Adolf DeISSMann, Licht vom Osten. Das Neue Testament und die neuentdeckten Texte der hellenistisch-römischen Welt, Tübingen $1923^{4}, 2$ ss.

8 Además de las obras de Horsley, cf. Sr. DominiQue Cuss, Imperial Cult and Honorary Terms in the New Testament (Paradosis 23), University Press, Fribourg 1974; A. Brent, The imperial Cult and the Development of Church Order. Concepts and Images of Authority in Paganism and Early Christianity before the Age of Cyprian, E.J. Brill, Leiden 1999. W. Carter, Matthew and Empire: Initial Explorations, Harrisburg, PA, Trinity Press International 2001; Michael Labahn - Jürgen Zangenberg (ed.), Zwischen den Reichen: Neues Testament und Römische Herrschaft, Vorträge auf der Ersten Konferenz der European Association for Biblical Studies, Francke Verlag, Tübingen - Basel 2002; Martin Ebner, Evangelium contra Evangelium. Das Markusevangelium und der Aufstieg der Flavier, en: Biblische Notizen 116 (2003) 28-42.

${ }^{9}$ Es sintomática la afirmación de John Dominic Crossan-Jonathan L. ReEd, In Search of Paul. How Jesus's Apostle Opposed Rome's Empire with God's Kingdom. A New Vision of Paul's Word \& World, Harper San Francisco, New York 2004, 412: "Who they were there and then, we are here and now. We are, at the start of the twenty-first century, what the Roman Empire was at the start of the first century. Put succinctly: Rome and the East there, America and the West here. Put more succinctly: they then, we now. Put most succinctly: SPQR is SPQA". Véase la recensión de este libro en P. Foster, Travelling with Paul and Undermining Rome, en: ExpTimes 117 (2006) 189-191. 
Las contribuciones del primer volumen del grupo editado por Horsley, muestran que este tipo de interpretación se remonta a los años $70^{10}$, especialmente a la década de los 80 y 90 . El círculo de participantes es relativamente grande. Sin embargo, los exegetas europeos están poco representados y éstos proceden fundamentalmente de los países escandinavos. También se encuentran, entre otros, Dieter Georgi o Helmut Koester, y se citan diversos artículos de G. Theißen y M. Hengel. Visto en su conjunto, parece que estamos ante una regionalización de la investigación. Hay que lamentar la falta de una recepción recíproca, lo cual se constata en la bibliografía empleada. Parece que el océano se agranda y separa cada vez más a los estudiosos americanos y alemanes. Esto también se confirma en ciertos encuentros internacionales, donde la confrontación de posturas se agudiza y se plasma en las discusiones, alguna de ellas no tan constructivas. En España ha pasado en cierto modo desapercibida dicha confrontación, o al menos no ha dejado una impronta excesiva en los estudios paulinos. Es más, parece que en muchos ámbitos aún no ha llegado la "new perspective" a los estudios paulinos"1.

El presente artículo tratará de presentar esta perspectiva de "Pablo anti-imperial", y analizar las aportaciones positivas, así como indicar las deficiencias o exageraciones que, según mi modesta opinión, se pueden constatar.

\section{Pablo y el "Politics Group"}

Según sus mismos fundadores, el grupo fue creado para ofrecer un foro común a las diversas líneas de criticismo de la misión paulina, de las cartas, y de las visiones comunes sobre Pablo. Estos estudios son realizados fundamentalmente por afro-americanos, judíos, exegetas de pueblos anteriormente colonizados ${ }^{12}$ y por quienes están dispuestos a cuestionar

10 Entre los precursores destaca KRISTER STENDAhL (Paul among Jews and Gentiles), quien modificó la focalización de la teología de Pablo, para centrarse en la gente con la que Pablo trabajó en su misión. El apóstol no pretendió crear una nueva religión. La presentación de Pablo como homo religiosus obsesionado con una conciencia introspectiva es una proyección cristiana occidental. Él nunca abandonó el judaísmo, y el primer encuentro con Cristo no fue una conversión a una nueva religión sino el encargo de la misión.

11 Únicamente conozco un artículo en castellano dedicado a esta temática, JUAN MIGUEL DíEz RoDElAs, La "nueva perspectiva sobre Pablo": Planteamientos y límites, en: Anales Valentinos 28 (2002) 209-229. Existen artículos traducidos del inglés que se encuentran en la web: www.thepaulpage.com.

12 En el contexto del poder imperial francés, británico y americano en el mundo, el "postcolonialismo" intenta reflejar la naturaleza y significado de esa experiencia (colonial 
la interpretación común de Pablo como un conservador político-social ${ }^{13}$ estrictamente obediente al imperio del que supuestamente era ciudadano. La denominación bajo la que se engloban todos estos grupos y perspectivas con el objetivo de cooperar en sus estudios es "Paul and Politics". La investigación se centra en cuatro áreas interrelacionadas y ampliamente concebidas, a saber: "Pablo y la política de las iglesias", "Pablo y la política de Israel", "Pablo y la política en el imperio romano" y "Pablo y la política de la interpretación".

Sus mismos miembros enuncian algunos de los principios que guían las discusiones del grupo: 1) Tanto los textos como las interpretaciones son lugares de confrontación y lucha. Pablo está discutiendo con adversarios o intenta silenciar otras voces discordantes en sus cartas. 2) Tanto la producción como la interpretación de textos conllevan relaciones de poder, intereses, valores, visiones... El apóstol utiliza el lenguaje no solo como transmisión de ideas, sino como una forma de acción que afecta a las personas mediante las relaciones de poder.3) Tanto los textos como los intérpretes ocupan lugares y contextos sociales concretos. En contraste con los estudios paulinos clásicos que preconizan la "objetividad", pero que despolitizan y domestican las cartas paulinas, es importante reconocer la lejanía política y cultural del texto para el lector moderno. Los textos están condicionados por su contexto histórico.

"Los objetivos y la agenda del grupo 'Pablo y la política' son, en sentido amplio, cuestionar, interrogar y revisar los textos e interpretaciones paulinas para identificar las formulaciones opresivas, así como las visiones y valores potencialmente liberadores con el objeto de recuperar sus posibilidades históricas no realizadas, todo ello en un compromiso crítico mutuo entre los diversos participantes. La diversidad de participantes, así como la heterogeneidad de teorías y enfoques, incluyendo 'lecturas desde abajo', pueden fomentar la desmitificación de prácticas problemáticas en la interpretación bíblica contemporánea... Conocimiento crítico significa realizar una elección para ejercer la crítica desde los marginados y oprimidos, y con la liberación en mente" 14 .

Segứn la visión de estos autores, todavía muchos estudiosos ven a Pablo a través de las lentes luteranas, es decir, lo interpretan en términos

e imperial, postcolonial y postimperial) para quienes están implicados en el imperialismo: los sometidos.

${ }^{13}$ El conservadurismo social de Pablo se ha visto reflejado fundamentalmente en los textos de 1Cor 7,17-24 y en Rom 13,1-7, lo que ha llevado a afirmar la acomodación religiosa de Pablo a la esfera social.

14 Richard A. Horsley, Paul and Politics 13. 
estrechamente religiosos, especialmente en contraste con la teología judía o la soteriología. Otro obstáculo para la lectura política de Pablo es la despolitización que ha sufrido el pensamiento paulino en la tradición cristiana, tendencia que ya se constata en los escritos tardíos del NT. Al final de la época de la composición del NT, los escritores cristianos comenzaron a enfatizar que los seguidores de Jesús no suponían un peligro para el poder romano establecido. Posteriormente se subrayará que los cristianos constituían un paradigma de lealtad al césar, a pesar de su lealtad religiosa exclusiva a Dios. Se consideró que la política imperial era el trasfondo donde se produjo la predicación paulina, pero Pablo se dedicó exclusivamente a la actividad religiosa. Como mucho, existieron algunas "implicaciones" políticas o sociales colaterales para su ministerio, pero las cuestiones imperiales permanecieron ajenas a Pablo. Pero ¿era ésta la verdadera intención de Pablo?

De los tres modelos fundamentales para la comprensión de la teología paulina y de la historia, los autores pertenecientes al Politics Group privilegian claramente el modelo apocalíptico escatológico, en contraposición a los que privilegian la doctrina tradicional de la justificación y de la denominada mística paulina. Al apóstol no le preocupa el problema jurídico del pecado ni el tema de la lejanía de Dios. Tampoco es central la cuestión de una unión mística con la divinidad. Más bien, la teología paulina está concebida como teleológica y teología histórica. Pablo estaba interesado en el triunfo de Dios sobre los poderes enemigos.

Desde esta nueva óptica, la interpretación de las cartas paulinas será totalmente distinta a la que estamos acostumbrados a escuchar. El evangelio y la misión paulina estaban en clara oposición al césar y al orden imperial romano, y no a la ley judía. Su evangelio es eminentemente político. Pablo pretendió establecer ekklesiai que fueran alternativas válidas a las asambleas de las ciudades, tales como las existentes en Tesalónica, Filipo, y Corinto. El apóstol coloca el evangelio de Cristo y las comunidades en oposición al poder imperial romano. Se enfrenta al sistema de valores de la sociedad romana, a las relaciones de poder ${ }^{15}$, a la ideología de paz y seguridad generada por la riqueza. Desafía el poder y el sistema de gobierno, en cuyo vértice se encontraba el emperador salvador.

Por tanto, los estudios paulinos deben cuestionarse: ¿por qué el poder romano y el orden imperial romano eran inaceptables para el apóstol y en

15 Las relaciones del poder imperial no se establecían únicamente por medio de la fuerza y la espada, sino que operaban de forma compleja a través de formas religioso-culturales intrínsecamente relacionadas con las formas económico-sociales de dominación. 
qué medida incidieron en su mensaje? Sin embargo, debido a la separación entre religión y política en los estudios occidentales de NT, se ha supuesto generalmente que tales cuestiones eran irrelevantes para la comprensión de Pablo. Es ahora cuando se ha comenzado a investigar la relación conflictiva del apóstol con el orden imperial romano, analizando en primer lugar la situación e ideología del imperio romano para conocer a qué se pudo enfrentar Pablo. Eso es también lo que vamos a exponer aquí de forma sucinta, para posteriormente situar a Pablo dentro de su contexto.

\section{El nuevo (des)orden mundial en tiempos de Augusto}

Las presentaciones recientes del mundo social del apóstol Pablo han perpetuado la visión común de que la pax romana proporcionó un contexto positivo para el nacimiento del cristianismo y la expansión de la misión paulina: viajes relativamente seguros mediante buenas vías de comunicación, mares libres de piratas y buenos puertos. El predominio de la cultura y del lenguaje griego facilitó la comunicación y la predicación. Augusto habría establecido un clima general de estabilidad y seguridad. Ése es el cuadro que nos presentan las fuentes epigráficas y literarias, que eran producto de la clase privilegiada. Como testimonio de esta teología imperial, destacan los autores ${ }^{16}$ que ensalzaron la figura de Augusto y la Pax Augusta mediante una poesía propagandista, a lo que hay que añadir los testimonios mudos de las monedas, el arte y la arquitectura ${ }^{17}$.

Los emperadores utilizaron hábilmente los cargos, los honores, el estatus y la administración para producir cohesión mediante una red de intercambio de relaciones personales que partía de ellos mismos. En el ámbito social y político, la sociedad estaba basada en el sistema de patronazgo. Se trataba de un elaborado sistema de relaciones vinculado especialmente al valor del honor. Las relaciones de patronazgo personal entre el emperador y la elite local constituían las líneas más importantes y efectivas a través de las cuales el poder fluía entre el centro (Roma) y las autoridades regionales y locales. Este sistema de poder jerarquizado era una forma más de mantener el orden público y ejercer el control sobre lós súb-

16 Caben destacar a Horacio, Virgilio, Ovidio, al mismo Augusto, así como otros textos del tiempo de Nerón (Calpurnius Piso, Calpurnius Siculus, Statius).

17 Ampliamente sobre este tema, cf. PAUL ZANKER, The Power of Images in the Age of Augustus, University of Michigan Press, Ann Arbor 1988. 
ditos. Gracias a la interrelación entre religión y estado, esta situación estaba sancionada por los poderes divinos. El sistema político-económicosocial del patronazgo estaba articulado de forma paralela y en fusión con el sisten:a político-religioso de los sacrificios y el culto al emperador ${ }^{18}$. La elite religiosa actuaba de la misma forma que la elite política.

La retórica pública ensalzaba también las relaciones de poder en el imperio'19. Las dos formas clásicas de establecer y mantener la conformidad de los pueblos conquistados eran el miedo a la espada y contentarlos mediante el arte de la persuasión. El tema fundamental en la oratoria de los inicios del principado giraba entorno a la paz, establecida y mantenida por el emperador, con el beneficio de la seguridad y bienestar para los habitantes del imperio frente ataques externos.

La obediencia provincial a la dominación romana fue una construcción ideológica. Su realización dependía de que muchas personas compartieran un conjunto de creencias que sancionaban una noción romana peculiar del orden social. Roma misma aportó la articulación inicial de los valores, a los que los súbditos orientaban su vida como miembros de la comunidad, y fue la creencia de que otros compartían esos mismos valores lo que legitimó la representación de Roma del orden social. Asentimiento y lealtad hacia Roma requerían el reconocimiento de que la construcción de la sociedad romana, en las relaciones entre las provincias, ciudades, individuos, emperadores e imperio, organizaba adecuadamente el valor colectivo de los compromisos de sus súbditos.

La concesión de la ciudadanía, las fiestas, las monedas, las imágenes imperiales, así como los conceptos y rituales políticos jugaron un papel importante dentro del mosaico multidimensional que honraba tanto al emperador como al gobierno. Las pretensiones romanas para legitimar el poder no se limitaban a la autoridad carismática del emperador. Roma

\footnotetext{
18 Recientes estudios del NT consideran que el sistema de patronazgo puede clarificar las relaciones existentes en las comunidades de Corinto, la interconexión y expansión del movimiento primitivo cristiano, y cómo ese sistema de relaciones proporcionó a los primeros cristianos un modelo para la conceptualización y descripción de sus relaciones con Jesucristo, como mediador, y con Dios, como patrón y benefactor celestial.

19 Rollin A. RAMSARAN, Resisting Imperial Domination and Influence. Paul's Apocalyptic Rhetoric in 1 Corinthians, en: RICHARD A. HorsLeY (ed.), Paul and the Roman Imperial Order, 89-101 recuerda que la retórica es política y que la retórica de Pablo debe ser leída en este contexto imperial romano. Independientemente de si Pablo se formó en la retórica greco-romana, él usa claramente modelos retóricos de su época. Su argumentación puede ser únicamente entendida en el contexto de la resistencia al poder imperial romano dentro de la tradición apocalíptica judía. En concreto, en 1 Cor, Pablo emplea formas grecoromanas junto a la retórica apocalíptica judía.
} 
también universalizó los beneficios de sus logros, es decir, mostró acuerdos institucionales que servían a los intereses de algunos individuos como si sirvieran a los intereses de toda la población. La ideología subyacente presentó el imperio como una colectividad que incluía a todos, minimizando las diferencias de cultura y clase, y enfatizando la similitud de las relaciones personales hacia el emperador ${ }^{20}$. Varias poblaciones del imperio, en particular, el oriente griego, reconocieron y apreciaron la estabilidad política y económica que proporcionó Roma.

Los nuevos estudios históricos, sin embargo, reflejan que esta situación tan idílica del imperio romano únicamente beneficiaba a una minoría dentro del imperio, a las clases privilegiadas. La inmensa mayoría de la población sufría sus consecuencias negativas ${ }^{21}$. Las cartas paulinas, $\mathrm{He}-$ chos y los escritos del historiador judío, Josefo y del filósofo Filón de Alejandría, muestran que el "nuevo orden mundial" impuesto por los romanos desde Augusto, era experimentado como desorden por muchas personas en las provincias. Los romanos y la aristocracia de los pueblos y ciudades que conquistaron, cuyo dominio ratificaron e incrementaron, lucharon por perpetuar un orden político-económico que aseguraba su propio poder y sus privilegios. Sin embargo, los pueblos sometidos no consintieron amablemente el nuevo orden imperial, y algunas de las disposiciones que impusieron, exacerbaron aún más los conflictos locales. Esto normalmente no se menciona, tal vez porque las fuentes literarias y epigráficas expresan el punto de vista de la elite.

Solo hace falta conocer un poco la historia de Judea - Galilea durante el siglo I d.C. para afirmar que la pax romana era una pesadilla de la que no podían librarse. Los movimientos de resistencia fueron reprimidos por los gobernantes por amenazar el orden imperial. Tanto los intentos fanáticos por conservar las formas tradicionales de religiosidad, como los intentos oficiales por tomar medidas drásticas contra la resistencia condujeron a un conflicto sangriento. Ésas eran las circunstancias de agitación, persecución y represión que tanto Pablo (Gal 1,13; Fil 3,4-6) como el libro de Hechos (4-5; 7,54-8,3) describen al presentar el movimiento de los seguidores de Jesús en Jerusalén y más allá de las fronteras judías. Dentro de las corrientes apocalípticas judías se encuentran duras críticas contra la

20 Sobre la ideología en el imperio romano, véase el capítulo segundo de CLIFFORD AnDo, The Imperial Ideology in the Roman Empire, University of California Press, Berkeley 2000, 19-48, aquí p. 40.

21 KLaus Wengst, Pax Romana. Anspruch und Wirklichkeit. Erfahrung und Warhnehmungen des Friedens bei Jesus und im Urchristentum, Chr. Kaiser Verlag, München 1986. 
dominación romana. Un ejemplo claro lo tenemos en el comentario de Habacuc (1QpHab) ${ }^{22}$.

La estabilidad política reinaba en otras ciudades en las que actuó Pablo, pero esta estabilidad impuesta por el poder imperial romano significaba inseguridad para la mayor parte de los habitantes. Sólo hace falta recordar los desplazamientos de pueblos conquistados y colonizados, que experimentaron el yugo de la dominación y ocupación romana. A ese yugo hay que añadir la esclavitud, era uno de los pilares sobre los que se basaba el orden socio-económico romano ${ }^{23}$.

\section{La política religiosa de Roma en tiempos de Augusto}

Debemos repensar el concepto de religión en la antigüedad. No se trataba de una creencia o fe basada en la relación personal con la divinidad, sino que tenía fundamentalmente un componente social, ya que no existía separación entre política y religión. De hecho, la política romana antigua estaba impregnada de expresiones y rasgos religiosos. La religión formaba un complejo entramado y un conjunto sutil de relaciones e interacciones mediante las que estaba estructurada la sociedad.

El velo que distorsionaba y encubría las duras realidades del imperialismo fue una ideología de la paz y seguridad que los dioses habían instaurado en y a través de Roma. Paz y seguridad fueron un logro de Augusto. El evangelio de Augusto celebraba esa "paz" lograda a través de la victoria, ya que la pax romana era generalmente impuesta sobre los pueblos gracias a la guerra o mediante la disuasión de las armas. Se trataba de una pax en sentido romano: se basaba en la guerra y en la conquista para pactar posteriormente con el pueblo conquistado. El mensaje del evangelio de Augusto era claro. Justicia y paz, los dones de los dioses, se han manifestado en la tierra en el orden y la seguridad impuestos por Roma. A los súbditos se les invitaba a responder con gratitud, temor y lealtad. Esta propaganda de Augusto utilizó todos los medios a su alcance (poesía, escultura y cultura en general) para realizar una reforma religiosa, política y social en todos los ámbitos, incorporando a este emperador a una compleja red de ritos, instituciones y eventualmente también de deidades.

22 Véase la versión española del Pesher Habacuc: Florentino García MÁrQueZ, Textos de Qumrán, Trotta, Madrid 1992,248-253, donde la justicia de Dios se opone a la de Roma. Cf. Salmos de Salomón 17.

${ }^{23}$ La visión positiva de la esclavitud es falsa. Esta lectura se basaba en una interpretación errónea de las directivas de Augusto, y en la falta de atención prestada a todo el sistema socio-político represor. 
Augusto renovó la moral y los valores tradicionales, las virtudes e ideales ${ }^{24}$. Restauró la religión romana y la moral tradicional, y de forma deliberada se propuso a sí mismo como paradigma. En el centro de toda la reestructuración del sistema religioso estaba Augusto, en ocasiones visto como el nuevo Rómulo ${ }^{25}$. Se convirtió en miembro de todos los sacerdocios y sodalities, proceso que culminó en el año 12 a.C., cuando asumió el cargo de pontifex maximus, fusionando en su misma persona los poderes políticos y religiosos. Pronto se consideró la época de Augusto como la realización de la Edad de Oro o la edad de Saturno. Los poetas resaltaron su pietas (especialmente Horacio), lo que conllevaba un cierto paternalismo, así como una vinculación especial a los dioses, para quienes restauró y construyó templos. La Pietas adquirió connotaciones del patronazgo imperial, a la que correspondía la lealtad (fides) entre el gobernante y los súbditos.

La figura de Augusto ocupará un lugar central en la vida política, religiosa y social romana. Aunque no existió en Roma un culto al emperador Augusto mientras aún vivía, sin embargo, su numen o poder divino sí recibió honores públicos. El culto al césar reinante no fue impuesto desde Roma, pues para la mentalidad romana no se podía adorar a un emperador viviente como dios ${ }^{26}$. En la capital del imperio, los emperadores y los miembros de la su familia sólo recibieron honores divinos después de su muerte y tras el reconocimiento de sus méritos. Pero veamos este tema con más detenimiento.

\section{EI culto al emperador ${ }^{27}$}

Los estudios del NT han mostrado siempre interés por el culto al emperador como una de las religiones más significativas en rivalidad con el

24 J.H.W.G. Liebeschuetz, Continuity and Change in Roman Religion, Clarendon Press, Oxford 19962 , 55-100. Mary Beard - John North - Simon Price (ed.), Religions of Rome. Vol. I: History, Cambridge University Press, Cambridge 1998, 313-363: "Roman Religion and Roman Empire".

25 Cf. S.R.F. PRICE, The Place of Religion: Rome in the Early Empire, en: The Cambridge Ancient History. X: The Augustan Empire, 43B.C.-A.D. 69, Cambridge University Press, Cambridge $2004^{2}, 820-847$, donde dedica especial atención a los cargos sacerdotales, a los templos y a los juegos seculares,

26 Cf. la actitud del emperador Claudio en su carta a los alejandrinos del año 41 d.C., PLond 1912, lín. 50-51; Dión Cassio, LX 5,4.

27 La literatura al respecto es inmensa. Véase p.e. D. Álvarez Cineira, Die Religionspolitik des Kaisers Claudius und die paulinische Mission (HBS 19), Herder, Freiburg 1999, 55-97 y especialmente el libro de S.R.F. Price, Rituals and Power. The Roman Imperial 
cristianismo ${ }^{28}$. Normalmente se centraba dicho interés en el objeto de la fe, especialmente si el emperador era considerado como un dios o si el culto expresaba una relación personal. Según la interpretación cristiana dominante, los conceptos y las frases del culto al emperador pronto se convirtieron en fórmulas manidas y en un lenguaje estereotipado. Los estudios modernos, sin embargo, consideran que los honores y las fiestas dedicadas al emperador no solo estaban ampliamente extendidos, sino que dominaban la vida pública, especialmente en las ciudades de Grecia y Asia Menor. Se afirma que el culto imperial, en sus múltiples manifestaciones, era un elemento religioso y político constitutivo del ambiente donde Pablo desempeñó su misión.

El culto al "hombre divino" no fue una característica peculiar y única del imperio romano. Las raíces del culto al emperador hay que buscarlas en diversas culturas antiguas del oriente próximo. Pensaban que los grandes gobernantes adquirían cualidades divinas. Roma realizó su propia contribución en este ámbito. El culto al emperador como personificación de una divinidad fue utilizado con fines políticos, como un medio para ensamblar diversos pueblos y culturas en un único imperio. En este proceso, Augusto jugó un papel relevante29.

Aunque los emperadores normalmente eran divi y no dei, fueron asociados e incorporados al culto de los dioses tradicionales ${ }^{30}$. Los espacios públicos $^{31}$ de las ciudades se convirtieron virtualmente en templos que dominaban el ágora, con estatuas imperiales y santuarios, inscripciones públicas y sus imágenes en las monedas. Se instituyeron festivales y juegos imperiales ${ }^{32}$. Las fiestas en honor del emperador se centraban en los eventos imperiales, por ejemplo el nacimiento (cf. el decreto del consejo provincial de Asia en 9 a.C. $)^{33}$, visto a veces como el inicio de una nueva era.

Cult in Asia Minor, Cambridge University Press, Cambridge 1984; Fritz Graf, Kaiserkult, DNP VI (1999)143-145; Mandred Clauss, Kaiser und Gott. Herrscherkult im römischen Reich, B.G. Teubner, Stuttgart - Leipzig 1999, 54-75.

28 Cf. Allen BRENT, The Imperial Cult 11-16; 73-130.

${ }^{29}$ Augusto se convirtió en divino de cuatro formas: por una descendencia ancestral de Venus y Anchises, por su milagrosa concepción (Apolo y Atia), por su adopción por parte del divino Julio César y por el decreto oficial del senado romano.

30 PAUL ZANKER, The Power of Images, en: Richard A. Horsley (ed.), Paul and Empire 72-86.

31 Cf. S.R.F. PRICE, Rituals and Power; Paul Zanker, The Power

32 Algunos autores consideran que únicamente existió el culto municipal para $\mathrm{Au}-$ gusto en Oriente, pero no se puede hablar de "culto provincial" dedicado a Augusto vivo, cf. D. Álvarez CineIra, Religionspolitik 58ss. Para la expansión del culto a Augusto en vida cf. Mandred Clauss, Kaiser 503-506.

33 U. LAFFI, Le iscrizioni relative all'introduzione nel 9 a.C. del nuovo calendario della provincia d'Asia, en: Studi classici e orientali 16 (1967) 5-98. 
Así, el culto imperial estructuró el tiempo y la vida urbana. La imagen del emperador se convirtió en omnipresente y fue ampliamente venerada en las ciudades griegas. Podemos decir que la relación entre gobernante y sus súbditos adquirió formas religiosas.

Los patrocinadores del culto imperial en las provincias fue la elite local que cultivó las relaciones estrechas con el emperador (o la familia imperial) mediante el patronazgo. Con ello consiguieron consolidar su propio poder. Las ciudades, como recompensa por el "altruismo" de esta elite provincial o local, los honraron otorgándoles los oficios públicos más prestigiosos y los sacerdocios imperiales o cívicos. Podemos resumir diciendo que el culto al emperador creó una vida cívica urbana que exigía, por una parte, lealtad al emperador y la estabilidad del imperio, y obtenía, por otra parte, beneficios políticos y económicos, así como reconocimiento social y honor en el ámbito local. El culto imperial se convirtió en la expresión y garantía más importante de la cohesión social. Asimismo, la participación en dicho culto se consideró como la mejor muestra de lealtad al imperio.

Como es de suponer, no todos los súbditos participaban de ese culto, especialmente quienes profesaban una religión monoteísta, como era el caso judío. A pesar del rechazo de las imágenes y de la devoción exclusiva a su dios judío, el conflicto con el culto imperial fue mínimo ${ }^{34}$. Ello se debía a que los emperadores generalmente no exigieron el culto de sus personas, y otorgaron a los judíos la facultad de vivir conforme a sus costumbres ancestrales ${ }^{35}$. Por su parte, el pueblo judío ofrecía sacrificios diarios por el emperador, lo que ya suponía una expresión de lealtad. Es en este contexto político-religioso donde tenemos que situar la actividad paulina.

\section{Pablo y el imperio Romano}

¿Constituía Pablo una amenaza para el orden público? Si tenemos en cuenta los esfuerzos del rey nabateo Aretas IV por arrestar a Pablo en

34 JAMES S. MCLAREN, Jews and the Imperial Cult: From Augustus to Domitian, en: JSNT 27.3 (2005) 257-278, examina seis casos de interacción judía con Roma y el culto imperial: "The absence of many examples, therefore, may not reflect any attempt on the part of Josephus to cover up the issue but could be an essentially accurate indication of the limited impact of the cult on Jewish-Roman relations" (274). Existía una frágil coexistencia en tiempos de Herodes entre el culto judío y los tres templos construidos por él y dedicados al emperador.

35 Para los privilegios de los judíos en el imperio, cf. D. Álvarez Cineira, Religionspolitik 160-170. 
Damasco (2Cor 11,32-33) y la aparente regularidad con que Pablo fue arrastrado ante los magistrados de las ciudades, encarcelado en prisiones romanas y condenado como una amenaza para el orden público (Filem 1,9,13; Filp 1,7.12-14.16; 4,14; 1 Tes 2,$2 ; 1$ Cor 4,9;2Cor $1,8-9 ; 6,5 ; 11,23)$, debemos cuestionarnos si el evangelio de Pablo era un mensaje puramente espiritual, tan cándido e inofensivo social y políticamente.

Hechos 17,7 relata cómo Pablo tuvo que huir para no ser apresado y llevado antes las autoridades locales de Tesalónica. Se acusa al apóstol y a sus colaboradores de ir en contra de los decretos del césar. Según K.P. Donfried debemos situar este texto dentro del contexto de los cultos existentes en Tesalónica. Cuando Pablo predica en Tesalónica, existía allí una fuerte teología imperial. No solo se dedicaron templos a Roma, sino también se erigió un templo al césar para honrar a los benefactores romanos de la ciudad. En las monedas se observa cómo el emperador ganó un estatus divino y su imagen casi suplanta a la de Zeus ${ }^{36}$. Los politarcas de Tesalónica eran los supervisores de ese culto. La predicación de Pablo (con los términos de euaggeliov, parousía, kyrios y pax et securitas) probablemente fue considerada subversiva y anti-imperial ${ }^{37}$. Por ello, se puede explicar fácilmente su rápida prohibición, así como las experiencias de sufrimiento y conflicto de esa comunidad.

¿Por qué Pablo provocó constantemente esta reacción si su evangelio era inofensivo políticamente, como la mayor parte de los comentarios sugieren? ¿Pudieron detectar las autoridades romanas en las palabras y acciones de Pablo una amenaza real para el orden social? ¿Era su praxis, de hecho, más comprometida con la realidad socio-política de lo que las lecturas convencionales han reconocido en los textos paulinos? ${ }^{38}$. Según el Politics Group, Pablo se inserta dentro de ese grupo de voces contestatarias al imperio. Su actividad misionera no se ha de entender como un misionero itinerante urbano que ofrecía una nueva experiencia religiosa, sino como embajador de un rey que estaba a punto de llegar, establecien-

36 MARIA R.-ALFÖLDI, Bild und Bildersprache der römischen Kaiser. Beispiele und Analysen (Kulturgeschichte der antiken Welt 81), Verlag Philipp von Zabern, Mainz am Rhein 1999. Véase: “zur Rolle der Kaiserbilder und zu ihrem Verständnis. Politische Hintergründe", pp. 10-21.

37 KART P. DONFRIED, The Cults of Tesalónica and the Thessalonian Correspondence, en: NTS 31 (1985) 336-356. No obstante, creo que este texto habría que relacionarlo mejor con el decreto del emperador Claudio del año 49, por el que expulsaba a los alborotadores "judíos y judeocristianos" de Roma y, si se quiere, con la política general de ese emperador, y no referido exclusivamente a Pablo, cf. D. Álvarez Cineira, Religionspolitik 261-274.

38 NeIL Elliott, Liberating Paul. The Justice of God and the Politics of the Apostle, Sheffield Academic Press, Sheffield 1995, 183. 
do células o grupos leales a este nuevo rey, y adaptando sus vidas, sus símbolos y praxis, así como sus mentes a la verdad del nuevo rey. La formulación de este mensaje era profundamente anti-imperial y subversiva a todo el entramado del imperio romano ${ }^{39}$. Existen numerosos indicios de que Pablo planteó premeditadamente su mensaje como una alternativa política; cuando acabó en prisión como consecuencia de su actividad "delictiva-propagandista", comprendió que había realizado su labor de forma satisfactoria. El apóstol se encontraba dentro del imperio, pero no pertenecía a él. Compartía el lenguaje del imperio e incluso formas concretas de persuasión; tomó prestados temas y términos del imperio y estableció comunidades que residían dentro de la cultura dominante. Sin embargo, utilizó estos temas y conceptos para articular su evangelio y constituir comunidades leales a un Señor y Dios, quien no solo era una alternativa, sino un rival del salvador imperial.

Pablo se embarca en una "intifida" ideológica contra la teología imperial. Es característica la formulación de N.T. Wright: La teología paulina fue "un reto muy importante precisamente al culto imperial y a la ideología que era parte del aire que respiraban Pablo y sus convertidos" 40 . Para Pablo, las rapsodias sobre una edad de oro romana eran un fraude. El slogan de la propaganda imperial "paz y seguridad" (cfr. 1Tes 5,3-6), con todo lo que ello implicaba, era un engaño. Por eso, el apóstol critica y condena la injusticia y la maldad de esta época presente, la impiedad (asebeia) y la injusticia (adikia) de los hombres ${ }^{41}$, que suprimen la verdad y así provocan la ira de Dios (Rom 1,18). La justicia de Dios se manifiesta (no como las proclamas del emperador, en el boato de ceremonias imperiales

39 Otros autores consideran, por el contrario, que Pablo aceptó el orden social y político de su época, cf. Bruno Blumenfeld, The Political Paul. Justice, Democracy and Kingship in a Hellenistic Framework (JSNTS 210), Sheffield Academic Press, 2001, 283s: "Paul, in other words, is the ideological guardian of the processes and structures of imperial power. Paul's political objective was to make the empire endure, toward off its decay by steeling it with a Christian ribband. Paul understood the political system he admired and used them to strengthen the Roman political system he admired and endorsed. He and later apologists (including the gospel writers) made Christianity comfortable for the ruling authority". La aceptación del sistema de impuestos es la prueba más clara de sumisión a un régimen político.

40 N.T. Wright, Paul's Gospel and Caesar's Empire, en: Richard A. Horsley (ed.), Paul and Politics 161.

41 John Dominic Crossan - Jonathan L. Reed, In Search of Paul. How Jesus's Apostle Opposed Rome's Empire with God's Kingdom. A New Vision of Paul's Word \& World, Harper San Francisco, New York 2004, x: "Paul opposed Rome with Christ against Caesar, not because that empire was particularly unjust or oppressive, but because he questioned the normalcy of civilization itself, since civilization has always been imperial, that is, unjust and oppressive". 
o mediante la solemnidad de decretos oficiales, sino) en la proclamación (evangelio) del mesías crucificado (Rom 1,16-17). Veamos algunos de los puntos más interesantes sobre Pablo que presenta el "Politics Group".

\subsection{La terminología paulina}

Antes que el cristianismo llegara a las ciudades de Asia Menor y Grecia, el culto imperial se extendió rápidamente en Oriente. Sin lugar a dudas, Pablo conoció su existencia cuando predicó en Asia Menor y en Corinto, donde floreció el culto imperial ${ }^{42}$. El contacto con el culto imperial dejó sus huellas en la presentación de la teología cristiana, especialmente en la terminología cristológica. Términos utilizados en el culto im-

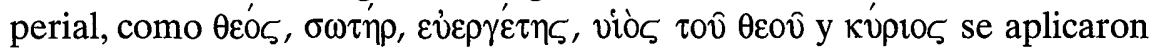
posteriormente a Jesús. Algo semejante acontece con la apoteosis del emperador elevado al cielo, imagen que también encontramos en la ascensión de Jesús (Hech 1,9ss). Asimismo, hallamos el tema de la epifanía y la parusía ( $\pi \alpha \rho o v \sigma i ́ \alpha)$ entre los romanos y en el NT ${ }^{43}$. El concepto parusía designa la llegada a una ciudad de un general, un oficial importante, un emisario imperial o del mismo emperador. Esta llegada era buena o mala para sus ciudadanos dependiendo de su relación previa con el que llegaba. La visita de un emperador a una ciudad era un evento irrepetible durante la Pax Romana, y seguramente constituía una ocasión feliz. Junto al término técnico de parusía, el apóstol emplea asimismo el concepto de $\dot{\alpha} \pi \dot{\alpha} \nu \tau \eta \sigma 15$ para cuando los cristianos tesalonicenses se encuentren con el Señor en su parusía $44(4,17)$. Otros conceptos utilizados por Pablo, como "evangelio", "cruz/crucificado", "salvación" e incluso "fe", eran términos provenientes de la ideología imperial.

La cuestión que se plantea es saber si el empleo de esta terminología cristológica se debe al influjo del léxico imperial con el objeto de propagar de forma comprensible lo acontecido en Cristo, o por el contrario se trata de una reacción o de expresiones conscientemente utilizadas para

42 En Corinto se adoraba al divus Julio César. También se dedicó un templo a Octavia (Pausanias, 2,3,1). Tras la muerte de Claudio, se instituyó un culto imperial provincial, como lo confirma una inscripción.

43 Cf. R. Reiser, Götter und Kaiser. Antike Vorbilder Jesus, München 1995, 137-142. Sobre la leyenda de Nerón redivivus cf. Tácito, hist 2,18,1; Suetonio, Nerón 57,1s.

44 Los muertos en Cristo resucitarán primero (1 Tes): según Crossan - J. Reed se refiere al martirio de algunos cristianos en la ciudad de Tesalónica. Para ello aduce la interpretación de 1 Tes 2,10 y 1,7-8. 
oponerse a la ideología imperial. Se han presentado varias respuestas a esta cuestión ${ }^{45}$. Los autores del Politics Group consideran que el vocabulario paulino fue utilizado conscientemente para oponerse a la ideología imperial. Por tanto, no es una mera adaptación del lenguaje, sino una confrontación buscada y deseada.

Así sucede en 1 Tes donde el énfasis recae sobre la llegada o el día del Señor Jesús, quien rescatará a los creyentes de "la ira que está llegando", mientras que la destrucción pende sobre los que confían en la "paz y seguridad" de la ideología imperial (1Tes 1,10; 2,19; 3,13; 4,13-18; 5,2-3). En 1 Cor, Cristo crucificado se contrapone no solo a la sabiduría, sino a los gobernantes de esta era, quienes están condenados a desaparecer. 1 Cor 15,23-28 utiliza un lenguaje claramente político. Según Neil Elliott, estos versículos, junto con el paralelo 2,8 , deben ser leídos dentro del contexto imperial romano, donde el poder último de Dios destruirá todo reinado o potestad de esta era. Los argumentos de Elliott corrigen la interpretación demasiado espiritualizada de los versículos y muestra que Pablo usa el lenguaje apocalíptico con una dimensión social.

También en la carta a los filipenses abundan conceptos claramente imperiales. La palabra $\sigma \omega \tau \eta \dot{\rho}$ fue utilizada en Oriente para los emperadores como un título honorílico (sal ador del mundo). Con este lirmino, los súbditos querían expresar al césar su gratitud por los beneficios y favores. Con el paso del tiempo, este concepto adquirió un significado divino. Aquí tenemos un claro paralelismo entre el lenguaje cultual cristiano y las fórmulas del derecho imperial y del culto al emperador ${ }^{46}$. El término кúpios fue frecuentemente utilizado en el culto imperial. Muchos exegetas consideran que el título de kv́ptos aplicado a Jesús se desarrolló en an-

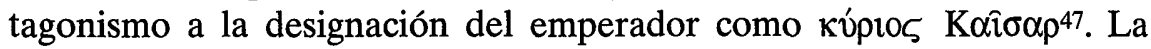
carta a los Filipenses utiliza el título kyrios ${ }^{48}$ en 15 ocasiones, lo que indica que el apóstol concedió una especial relevancia a este epíteto aplicado a Jesús. La insistencia en la cristología del kyrios hace suponer que el con-

45 H.-J. Klauck, Die religiöse Umwelt des Urchristentums. Bd. 2: Herrscher- und Kaiserkult, Philosophie, Gnosis, W. Kohlhammer, Stuttgart 1996, 74, aconseja no sobrevalorar en exceso la influencia del culto imperial para el NT: "Niemand wird einfache Übernahmen und Ableitungen postulieren wollen".

${ }^{46}$ A. DAISMANN, Licht 275. Para el significado de $\sigma \omega \tau \dot{\eta} \rho$ entre los griegos y cristianos, véase D. Cuss, Cult 63-71.

47 Ya K. Bornhäuser, Jesus Imperator Mundi (Phil. 3,17-21 und 2,5-12), Gütersloh

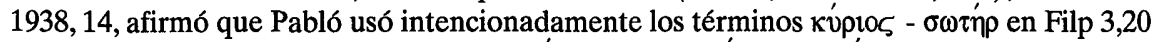

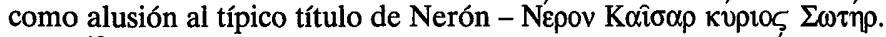

$48 \mathrm{Cf}$. también 1 Cor 2,8: Pablo utiliza aquí el término kúplos para Jesús en contraposición a los señores del mundo; 1 Cor 8,6; Hechos 25,26 (Festo para el emperador). 
flicto en Filipo se trataba de un enfrentamiento entre el evangelio de Jesús y la ideología romana. Para Pablo, Jesús es el kyrios único y universal.

Dieter Georgi ${ }^{49}$ estudia la carta a los romanos. Analiza los términos euangelion (el evangelio del salvador imperial), pistis (la lealtad o fidelidad al césar/Roma) dikaiosyne (la justicia impuesta por el emperador) y eirene (la paz o el buen orden asegurado por la conquista romana), dado que son conceptos centrales. Este autor resalta las asociaciones de dichos términos con la teología política de Roma. Ya que Pablo usa deliberadamente un lenguaje asociado a la religión imperial, esto hace suponer que estaba presentando su evangelio en rivalidad directa con el evangelio del césar. En el lenguaje político-diplomático, evangelio significaba la "noticia de victoria". Pablo parodia así las pretensiones de la dinastía julio-claudiana. N.T. Wright ${ }^{50}$ relaciona el aspecto de euaggelion proveniente del AT (Isa $40 ; 52$ ) con el aspecto político. Según Isaías, Dios es el único soberano del mundo. Este mensaje debió ser entendido como una llamada directa a abandonar otras lealtades y ser leales a Jesús, como también refleja Hechos 17,7 .

El apóstol no se conforma con utilizar la terminología imperial, sino que también emplea la retórica deliberativa con contenido político ${ }^{51}$. En 1 Cor 1,10-12 tenemos el lenguaje técnico de la oratoria política (el tema de la unidad política frente a las divisiones), lo ventajoso para el interés

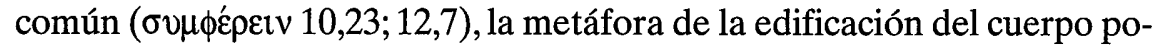
lítico $(3,9-17 ; 6,9 ; 8,1.10 ; 10,23 ; 14,3-5 ; 12,17.26)$ y la analogía de la cooperación de los miembros de un cuerpo, uno de los paradigmas comunes para el cese de divisiones en la retórica política griega.

Aunque utilizó los recursos retóricos romanos, sin embargo Pablo rechazó el alto valor que la cultura dominante otorgó a la persuasión retórica $(1,17-20 ; 2,1.4 ; 4,19)$, y se ofreció a sí mismo como ejemplo de comportamiento al que invitaba a emular. Su ethos era todo lo contrario a lo que ofrecían las virtudes aristocráticas y los valores estándar en la retóri-

\footnotetext{
49 Cf. Dieter Georgi, Theocracy in Paul's Praxis and Theology, Minneapolis, Fortress Press 1991; Neil Elliot, Liberating Paul.

50 N.T. Wright, Paul's Gospel 165.

51 Richard A. Horsley, Rhetoric and Empire - and 1 Corinthians, 72-102. cf. La retórica suplanta a la guerra como medio persuasivo (Séneca, Clem 49: Conmigo, la espada está escondida, mejor dicho, está envainada). "Paul used the standard political rhetoric of unity, concord, and common advantage versus civil strife, in effect, to subvert the established "political" order". Cf. Christopher Forbes, Paul and Rhetorical Comparison, en: J. Paul Sampley, Paul in the Greco-Roman World. A Handbook, Trinity Press International, Harrisburg - London - New York 2003, 134-171.
} 
ca griega. Se presentó como débil, loco, pobre (trabajar con sus propias manos para vivir), necio y despreciado; padeció hambre, sed, desnudez y malos tratos. Se convirtió en la basura del mundo $(4,8-13)$.

\subsection{El evangelio paulino anti-imperial}

Durante los años 50, el apóstol viajó a través de las ciudades griegas de la costa mediterránea, Tesalónica, Filipos, Corintio, proclamando el "evangelio de Cristo" (1Cor 9,12; 2 Cor 2,12; 9,13; Filp 1,27; 1Tes 3,2). Por aquel entonces, el "evangelio del emperador" ya se había propagado en esas ciudades. Pablo aseguró a los filipenses que podían esperar un "Salvador del cielo". Pero el salvador imperial ya había establecido e instaurado "paz y seguridad" a lo largo del mundo mediterráneo, y las ciudades de Grecia y Asia Menor honraron a su salvador mediante la dedicación de templos, fiestas y juegos. Pablo predicaba que Dios había exaltado a Jesús sobre todo y que toda rodilla se dobla y toda lengua profiere que Jesucristo es Señor (Filp 2,9-11). Sin embargo, el señor divino, a quien todos prestaban obediencia y a quien todos declaraban lealtad ("fe"), ya había sido entronizado y ensalzado en Roma.

Este himno de Filp 2,5-11constituye un reto y un desafío a la teología imperial romana. El texto subvierte e incluso satiriza cómo millones de personas dentro del imperio romano adoraban a alguien con "forma de Dios", pero que en realidad no lo era. Esa insolencia no podía pasar desapercibida, además teniendo presente que este mensaje subversivo provenía de una persona que había tenido dificultades con la justicia romana en diversas ocasiones y lugares, y que proponía a alguien con "forma de Dios" (Jesús), que había estado encadenado en un praetorium proconsular, condenado y ajusticiado por el poder romano. Eso visualiza claramente en Cristo el choque de dioses y evangelios, entre la justicia de la alianza judía y la "normalidad" imperial romana. ¿Es la señoría de Cristo, ahora en el cielo cristiano, totalmente diferente de la señoría del dictador, ahora en el cielo romano? Jesucristo, en el cielo cristiano, no es Augusto en el cielo romano con un nombre diferente 52 .

En el análisis de este texto, Peter Oakes ofrece paralelos de ascensiones al trono imperial. De la comparación de dichos pasajes con Filp, concluye este estudioso: "Cualquier oyente greco-romano probablemente

52 J.D.Crossan - J. Reed, In Search of Paul 290-292. 
escucharía en estas palabras una comparación con el emperador"53. ¿Qué decir a esto? Parece que todos los indicios apuntan a que Pablo está ofreciendo aquí una interpretación cristiana de Isaías 45 y 52,13-53,12. La expresión "toda rodilla se doble" y "toda lengua proclame" no se encuentra en la retórica imperial. Se trata claramente de una referencia a Isa 45,23 (LXX). La palabra "exaltar" (i $\pi \varepsilon \rho v ́ \psi \omega \sigma \varepsilon v)$ no aparece en la retórica imperial, ni en la literatura griega, sino en Filipenses y Salm 96,9 (LXX). Incluso, la expresión "por eso" ( $\delta$ iò $\kappa \alpha \grave{i})$ de Filp 2,9 no hay que identificarla como un paralelo del motivo por el que el senado concedió su autoridad

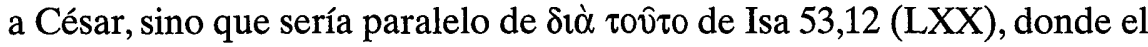
siervo es exaltado por haberse humillado en favor de otros. Tendríamos aquí una identificación de Jesús con el siervo del Deutero-Isaías.

Lo importante no es a quién se refieran estas imágenes del himno, sino lo que Pablo quiso que los filipenses pensaran cuando las usó. ¿Cuál era el objetivo concreto del uso de esta imaginería? El mismo apóstol responde a esta cuestión en Filp 2,2-4. Los filipenses no debían atribuir a otra persona los reclamos arrogantes de grandeza, ni siquiera a Adán o a Julio César, sino a la humildad de Cristo, y cómo ellos debían identificarse con él. "El himno de Filipenses es, entonces, un puntal en la exhortación de Pablo a los Filipenses para mantenerse firmes y, sobre todo, para estar unidos; es un elemento que juega su parte en el objetivo retórico de Pablo, para ofrecer el 'consuelo' a los creyentes en Filipo"54.

Más chocante era el uso del concepto euangelion ${ }^{55}$. En Corinto, euangelion era la "buena nueva" de "salvación", "paz y seguridad" establecida por el salvador imperial, Augusto y sus sucesores; paz y seguridad alcanzada mediante medios convincentes de "disuasión forzosa", tales como la crucifixión de los súbditos que tuvieran la audacia de oponerse al dominio romano. Este evangelio era anunciado en monedas e inscripciones y celebrado en las fiestas de las ciudades imperiales en honor del emperador. Como parte de la celebración de este evangelio del salvador imperial, se ofrecían sacrificios de gratitud en los templos y santuarios que dominaban los espacios públicos de Corinto y de otras ciudades griegas. Pablo enseñaba un evangelio alternativo ${ }^{56}$, ése de un líder de la gente sometida,

53 Peter OAKes, Philippians. From People to Letter (SNTSMS 110), Cambridge University Press, Cambridge 2001, 147.

54 ChRISTOPHER BRYAN, Render to Caesar 88.

55 Para el uso del concepto cf. Helmut KoEster, Ancient Christian Gospels, Trinity Press International, Philadelphia 1990, 1-6.

56 La confrontación más llamativa entre el evangelio imperial y el evangelio paulino es su "teología" en relación con la política. La ideología imperial subrayaba que Júpiter y 
que había sido crucificado por su resistencia al poder imperial. El evangelio del crucificado era una necedad, ya que se oponía a los valores dominantes de la aristocracia y afirmados en cualquier discurso público. Anunciar el evangelio del crucificado era al mismo tiempo una locura en el sentido de un suicidio político, pues podía atraer la atención de los romanos y llevar a éstos a mantener la paz con la violencia, cuando la persuasión y la intimidación no eran suficientes ${ }^{57}$.

Además, este evangelio anti-imperial proclamaba que Jesús había sido justificado por Dios, resucitado y exaltado como señor celestial (1 Cor 2,8; 15,3-4; Fil 2,6-11). En el contexto imperial, esto significaba que Jesús había asumido la posición del emperador, y su muerte fue una mera transición para su apoteosis. En 1 Cor y en Filp 3, Pablo articuló explícitamente las implicaciones políticas anti-imperiales del entronizamiento celestial de Cristo como el verdadero Señor o emperador del mundo. Un pasaje clave es 1 Cor 2,6-8, donde en el "misterio" (plan) apocalíptico de Dios, "los gobernantes (archontes) de esta época, están sentenciados a perecer", porque cometieron el error de crucificar al "Señor de la gloria". Igualmente escandalosa era para un romano la afirmación paulina de que Cristo estaba a punto de "destruir todo principado, toda potestad y todo poder... Pues es necesario que Cristo reine hasta que Dios ponga a todos sus enemigos bajo sus pies" (1Cor 15,24-28). Dios ha elegido lo débil de este mundo frente a los poderosos, a los ricos y a la elite sabia que domina el sistema imperial $(1,26-27 ; 4,8-10)$. Los elegidos, los santos, pronto participarán en el juicio divino contra el sistema romano, cuya forma es pasajera $(6,1-4 ; 7,13)$.

Este mismo lenguaje imperial también se encuentra en otras cartas. Así, el uso y contenido de $\sigma \omega \tau \eta$ pí (1Tes 5,8-9; Filp 1,28; 2,12; Rom 1,16; $10,1 ; 13,11)$ pudo ser entendido como una alternativa a esa salvación ofrecida por Augusto y sus sucesores. Pablo se opone a la "paz y seguridad" que la propaganda imperial se jactaba de haber establecido en todo el mundo. Claramente, Filp 3,20-21 se presenta como uno de los textos donde Pablo predicaba un evangelio anti-imperial, dado que evoca ecos del culto y de la ideología imperial ${ }^{58}$. Mediante el empleo del concepto po-

los dioses habían entregado el poder a Augusto. Por el contrario, Pablo insiste en que Cristo es quien está reinando ahora en el cielo y "después de toda potestad, autoridad y poder" entregará el reino a Dios Padre, de modo que Dios sea todo en todos (1Cor 15,24.28).

57 RICHARD A. HORSLEY, Rhetoric and Empire - and 1 Corinthians, 91s.

58 La llegada de Pablo a Filipo la describen J.D. Crossan - J.L.Reed, con las siguientes palabras: "With Paul... came Rome's most dangerous opponent - not legions but ideas, 
lítico de "soter" (salvador) en el clímax de la argumentación de Filp 3,2021 , Jesús salvador es contrapuesto al salvador imperial ${ }^{59}$. Cristo se ha convertido en el verdadero salvador, quien instaurará el orden político divino para su asamblea $(3,19-21)$. Las traducciones e interpretaciones han intentado atenuar las implicaciones políticas mediante recursos de individualización (ciudadanía) y espiritualización (celestial). Los filipenses eran conscientes que desde la batalla de Accio tenían un salvador y señor. Ése era el evangelio imperial. La presentación de la exaltación de Jesús y la entrada en el cielo que nos presenta el. himno (Filp.2,6-11); debió hacer pensar en los eventos que rodeaban la muerte de un princeps y su ascensión al cielo o apoteosis ${ }^{60}$. Cristo Jesús ha desplazado al césar como emperador, al haber sido exaltado y al concedérsele el nombre que está por encima de todo nombre (2,9). Estos préstamos lingüísticos y las alusiones al lenguaje del culto del emperador y de la ideología revelan la carga antiimperial que comportaba el evangelio paulino.

Seguramente que el aspecto anti-romano más patente de su mensaje fue su insistencia en el Cristo crucificado, tal y como lo demuestra Neil Elliott. La crucifixión era el medio más horrendo mediante el cual los romanos torturaban hasta la muerte a quienes se oponían al dominio romano, de modo que sirviera de escarmiento para el resto de la población. Pablo se refiere a este atroz hecho en su carta a los Galatas: "¿No fue exhibido Cristo públicamente ante vuestros ojos como crucificado?" (Gal 3,1). En las ciudades griegas, dominadas política y culturalmente por una elite pro-romana y sus valores aristocráticos, sin lugar a dudas, debió ser

not an alternative force but an alternative faith. Paul too proclaimed one who was Lord, Savior, Redeemer and Liberator. He announced one who was Divine, Son of God, God, and God from God. But Paul's new divinity was Christ, not Caesar" (9s).

59 Filp 3, 20 contendría un desafío codificado paulino al imperio. El texto usa diversos títulos imperiales que vienen aplicados a Jesús. El imperio del césar, de la que Filipos es un puesto de avanzadilla, es la parodia; el imperio de Jesús, del que la iglesia de Filipos es un puesto de avanzadilla, es la realidad. Y la intención de "nuestra ciudadanía está en el cielo" no se refiere a una eventual retirada y regreso a la ciudad madre. Si las cosas se complicaban en la ciudad colonial, el emperador vendría desde la ciudad matriz y liberaría a sus súbditos, transformando la situación de peligro en seguridad. Por tanto, la referencia a Jesús refleja ecos de la escatología imperial, aunque evidentemente también derivaba de fuentes judías como acontece en 1 Cor 15,25-28.

60 Hemos de tener presente que pocos años antes había tenido lugar la apoteosis y la divinización del emperador Claudio (54 d.C.): Suetonio, Claud 44,3; Nerón 8; Tácito, ann. 12,69; 13,2; Séneca, apocol. 2,2. Con la apoteosis, se le otorgó a Claudio en Occidente el título de divus como testimonian las inscripciones, en Oriente el título de Theos o Theos Epiphanes; ampliamente sobre este tema cf. D. Álvarez Cineira, Religionspolitik 76-89; J.C. RICHARD, Les funérailles des empereurs romains aux deux premiers siècles de notre ère, en: ANRW II 16.2 (1978) 1128. 
una "locura" (1Cor 1,23) así como una afirmación política antirromana proclamar y organizar comunidades en torno a un criminal político crucificado. Incluso, se proclamaba que este insurrecto político, crucificado por los romanos, había sido entronizado como verdadero señor del mundo y estaba a punto de regresar en la parusía (una referencia a la entrada imperial en una ciudad sometida). El crucificado por los dirigentes romanos era ahora el señor, quien sometería pronto "todas las cosas", presumiblemente incluyendo a los gobernantes romanos (cf. 1 Cor 15,24-28; Filp 3,2021).

En las cartas a los romanos ${ }^{61}$ y a los gálatas, el mensaje anti-imperial está menos explícito. Al comienzo de su largo discurso en Rom 1-11, Pablo afirma que Cristo ha suplantado al césar, ha sido declarado hijo de Dios con poder $(1,4)$. En toda la argumentación de Rom 1-11, está implícita la creencia de que la historia, tal y como Dios la llevará a cumplimiento, no pasa a través de Roma, todo lo contrario a los presupuestos y a la propaganda en la metrópoli imperial.

La crucifixión, la resurrección y la parusía son todos ellos eventos con un significado político; los dos primeros ya han acontecido y el tercero es inminente, con implicaciones obvias para el orden imperial romano. En el uso de términos y símbolos de la oratoria pública política y de la ideología imperial, Pablo estaba proclamando un evangelio alternativo al mensaje imperial. Para esta presentación, el apóstol estuvo claramente influido por el apocalipticismo judío62. Georgi, Koester y Elliot indican que el empleo anti-imperial del lenguaje y los símbolos imperiales por parte de Pablo, formaba parte de su propio trasfondo apocalíptico judío y de su visión del mundo. Las interpretaciones, que subrayan la perspectiva teológica cristiana, han oscurecido la carga y fuerza política anti-imperial de las afirmaciones paulinas, en parte porque han tendido a seguir la espiritualización deuteropaulina del lenguaje paulino. En las cartas deuteropaulinas, Colosenses y Efesios, presentan a los nuevos poderes y gobernantes cósmicos como creados por un Cristo preexistente (no-paulino) (Col 2,16; 2,10), sobre quienes triunfa en su crucifixión (Col 2,15; vs. 1 Cor 2,8; 15,24). Para el autor de Efesios, Pablo afirma que "nuestra lucha no es

\footnotetext{
61 JACOB TAUBES, Politische Theologie 27, considera que la carta a los romanos es una teología política, "eine politische Kampfansage an den Cäsaren".

62 La perspectiva que estructura sus argumentos en 1 Cor, sin embargo, aparece que está muy influenciada por la literatura apocalíptica judía, un objetivo principal de ésta fue la resistencia a los imperios helenistas y romanos que amenazaban el estilo de vida tradicional judío (bíblico).
} 
contra enemigos de carne y sangre, sino contra los gobernantes, contra las autoridades, contra los poderes actuales de las tinieblas, contra las fuerzas espirituales de mal en los lugares celestiales" (Ef 6,12). Por tanto, se ha mistificado el evangelio anti-imperial paulino.

\subsection{Pablo frente a los valores sociales romanos}

Basándose en la investigación de historiadores clásicos, Erik Heen 63 expone cómo Pablo usó una imagen clave de la ideología imperial para oponerse a ella. La pasión aristocrática por los honores sería el factor clave para explicar el sistema de patronazgo con el objeto de obtener favores del emperador. Para ello, el patrón se debía mostrar generoso en la construcción de espacios y edificios públicos (euergestimo), lo que efectivamente aseguraba su posición de poder, privilegio y dominio local. Heen propone este contexto del patronazgo para la interpretación del himno de Filp 2,6-11. En lugar de ser una expresión cristológica de la preexistencia de Cristo, este himno usa una frase clave del culto imperial para representar a Cristo como quien se opone al emperador: lejos de valorar y buscar los honores iguales a Dios, Jesús fue martirizado por las autoridades romanas (en la cruz), después de lo cual fue elevado a una posición más elevada que el emperador, como contra-emperador. Tomando los modelos de resistencia de James C. Scott, Heen muestra cómo las comunidades paulinas se forjaron un espacio para constituirse en una comunidad alternativa, viviendo un conjunto de valores tomados de imitar a Cristo (y no al césar), el verdadero reinante de sus vidas, precisamente porque se convirtió en paradigma del servicio mutuo.

Pablo mismo cuestiona el sistema de relaciones basado en el patronazgo, que mantenía el imperio cohesionado de forma piramidal ${ }^{64}$. La estructura vertical de patrón-cliente estaba en conflicto con el sentimiento profundo cristiano de que la simetría horizontal y la igualdad debían gobernar las interrelaciones sociales de los cristianos. La razón teológica

63 Eric M. Heen, Phil 2:6-11 and Resistance to Local Timocratic Rule: Isa theo and the cult of the Emperor in the East, en Richard A. Horsley (ed.), Paul 125-153.

64 Efrain Agosto considera que las cartas de recomendación greco-romanas están en función de este sistema de patronazgo, las cuales relacionan a personas de un rango social inferior con otro superior. Por el contrario, los pasajes de recomendación paulina difieren sustancialmente de las cartas de recomendación que buscaban posiciones de poder y status para mejorar la posición de las carreras personales de miembros de la elite romana o provincial. 
para esta igualdad hay que buscarla en la relación con Dios: todos eran considerados iguales ante Dios 65 .

En Rom 1,16-17 se proclama la justicia de Dios. La diosa romana Iustitia, como el mismo culto del emperador, era una novedad en el mundo paulino: el templo dedicado a Iustitia fue erigido el 8 enero del año 13 d.C. y celebrada por Augusto entre las virtudes más excelsas ${ }^{66}$. Estaba tan íntimamente vinculada la virtud de la Iustitia con el régimen imperial, que esta diosa a veces adquirió el título de "augusta". Así, sin perder ninguno de los significados enraizados profundamente en el judaísmo de la fidelidad a la alianza de Dios creador, la declaración de Pablo de que el evangelio del rey Jesús revela la dikaiosyne de Dios debió ser entendido como un desafío a la pretensión imperial. Si se quiere la justicia, ésta no se encontrará en el euaggelion que anuncia al emperador como señor, sino en el euaggelion de Jesús ${ }^{67}$.

Jennifer Wright Knust ${ }^{68}$ considera que Pablo critica la moralidad instaurada por el imperio (1Tes 4,3-7; Rom 1,18-32; 1Cor 6,15). La ideología imperial romana afirmaba que Augusto y sus sucesores habían restaurado la moralidad pública intentando implantar la ley y velando por las costumbres ${ }^{69}$. En este contexto imperial, Pablo declara que la sociedad está corrompida y abunda la fornicación, afirmación que habría sido entendida como una crítica al emperador y al imperio: el emperador ha fracasado en su intento por restaurar la moral pública. Cristo es la verdadera respuesta al pecado.

\subsection{Pablo y el orden natural}

Robert Jewett demuestra que la oposición entre Pablo y el orden imperial romano incluye incluso la comprensión del orden natural. Este

65 Cf. Peter Lampe, Paul, Patrons and Clients, en: J. Paul Sampley, Paul in the GrecoRoman World 488-523; J.K. Chow, Patronage and Power. A Study of Social Networks in Corinth (JSNTSup 75), Sheffield Academic Press, Sheffield 1992.

66 En el 27 a.C., el senado reconoció los logros políticos excepcionales de Augusto alabando su virtus, clementia, iustitia y pietas (cf. Res gestae divi Augusti 34,1-3).

67 N.T. Wright, Paul's Gospel and Caesar's Empire 172.

68 Jennifer Wright Knust, Paul and the Politics of Virtue and Vice, en: Richard A. Horsley, Paul and the Roman Imperial Order, Trinity Press International, Harrisburg - London - New York 2004, 155-173.

69 J. Rufus Fears, The Cult of the Virtues and Roman Imperial Ideology, en: NWRW II 17.2 (1981) 885-86. Cf. Horacio, Carm 4,5. 
autor $^{70}$ examina Rom 8,18-23 y lee el pasaje de forma novedosa. Presupone que su trasfondo era la ideología imperial del renacimiento de la naturaleza. Central para la propaganda de Augusto y sus sucesores fue la cantidad de monumentos, tales como el ara pacis, y las fiestas conmemorativas que pretendían reivindicar que su paz imperial había restaurado la Madre Tierra y llevado a ésta a una época de verdadera fertilidad y productividad sobrenatural, lo que significaba una edad de oro y de prosperidad. En las comunidades cristianas de Roma, Pablo se dirige a una audiencia que conoce muy bien las conquistas imperiales y la explotación económica, que ha devastado ciudades y campos, desforestado montañas y erosionado el medio ambiente natural. Pablo les indica que el mundo se encuentra gimiendo y sufriendo, esperando su liberación, del mismo modo que "los hijos de Dios" se encuentran sujetos a la futilidad del mundo por la arrogancia y los pecados de la praxis imperial. Frente a esa situación, propone una "nueva creación" (2Cor 5,17; Gal 6,15), que conlleva la responsabilidad colectiva por la creación.

\subsection{Pablo y el simbolismo imperial}

Neil Elliott ${ }^{71}$ explica cómo Pablo tomó prestados aspectos simbólicos de la ideología imperial romana para oponerse al imperio. Analiza la imaginería del triunfo imperial que detecta en 2 Corintios. Acentuando el contraste y oposición a la procesión imperial que aclama el poder irresistible del héroe militar, Pablo se retrata a sí mismo como víctima derrotada por la violencia imperial. En esta inversión de la representación pública del triunfo imperial, el poder de Dios se manifiesta en la humillación de Pablo y en la crucifixión de Cristo, porque la crucifixión de Cristo a manos los "potentados de este mundo" es el evento inaugural por el que Dios somete a las autoridades imperiales.

De forma semejante, Larry J. Kreitzer considera la imaginería triunfal romana como trasfondo de 2 Cor 2,14-16 y Col 2,15. Observando el uso del verbo thaiambeuein, sugiere que la idea del triunfo militar romano era ampliamente conocida en el mundo antiguo. El triunfo de las legiones ro-

70 RoBERT JEWETT, The Corruption and Redemption of Creation: Reading Rom 8:1823 within the Imperial Context, en: Richard A. Horsley (ed.), Paul and the Roman Imperial Order 25-46.

71 Neil Elliott, The Apostle Paul's Self-Presentation as Anti-Imperial Performance, en: R. Horsley (ed.), Paul 67-88. 
manas sobre sus enemigos se celebraba tanto en las obras literarias como en los mass media de la época (escultura, pintura, grabados...). Pablo seguramente tenía en mente esta imaginería cuando escribió 2 Cor 2,1472 y Col 2,15. Esta imaginería también ha dejado sus huellas en la numismática. Diversas monedas representan la procesión triunfal, donde varios esclavos y personas de países conquistados precedían al emperador, quien iba detrás, en su carro triunfal, para presenciar la muerte de los prisioneros en la colina capitolina. Los testimonios numismáticos nos llevan a pensar que la imaginería triunfal está íntimamente relacionada con la comprensión paulina de su apostolado, como alguien que afronta la muerte por causa de Jesucristo. Este contexto ayuda a entender pasajes como 2 Cor 4,8-12 y 11,23-27, donde Pablo mezcla sus ideas sobre el ministerio y la muerte ${ }^{73}$.

\subsection{Rom 13,1-7 74}

En la carta a los romanos, Dieter Georgi 75 ve una contraposición entre la teología misionera paulina y la teología política romana expresada en la terminología utilizada. Así, Pablo escribe una sátira a la sucesión en el trono de Claudio (Nerón) en Rom 1,3-4. El senado romano declaró

72 Sobre el trasfondo cultural y religioso de este texto véase Roger DAVID Aus, Imagery of Triumph and Rebellion in 2 Corinthians 2:14-17 and elsewhere in the Epistle. An Example of the Combination of Greco-Roman and Judaic Traditions in the Apostle Paul (Studies in Judaism), University America Press, Lanham, MD - New York - Oxford 2005, expone la "imaginería" de los triunfos romanos (pp.1-46) así como la imaginería judaica de rebelión basada en Num 17,6-15 (pp. 47-79). Aparecen los elementos romanos de la acción de gracias y el incienso. Según este autor, el pasaje muestra a Pablo y a sus colaboradores no como prisioneros capturados, sino como oficiantes victoriosos marchando con Dios a la cabeza de la procesión. La ovatio (procesión triunfal celebrada cuando un general romano ganaba una victoria mediante la persuasión) sería un modelo para la imaginería paulina. Menos convincente es el triunfo que este autor presupone para el texto: el de Lucio Aemelius Paulus celebrando la victoria sobre los macedonios (167 a.C.). Para Col 3,11 cf. Harry Om Maier, Barbarians, Xcythians and Imperial Iconography in the Epistle to the Colossians, en: A. Weissenrieder - F. Wendt - P. von Gemünde (eds.), Picturing the New Testament. Studies in Ancient Visual Images (WUNT 193), Mohr Siebeck, Tübingen 2005, 385-406.

${ }^{73}$ LARRY J. KREITZER, STRIKING New Images. Roman Imperial Coinage and the New Testament World (JSNT.Supplement Series 134), Sheffield Academic Press, Sheffield 1996, 145.

74 Para este apartado puede verse el artículo de Stefan Schreiber, Imperium Romanum und römischen politischer Sprechweise in Röm 13, en: Ulrich Busse (Hg.), Die Bedeutung der Exegese für the Theologie und Kirche (QD 215), Herder, Freiburg - Basel - Wien 2005, 131-168.

75 DieTER Georgi, God Turned Upside Down, en: R.A. Horsley (ed.), Paul and Empire 148-157. 
la consecratio de Claudio, es decir, su apoteosis. Séneca ${ }^{76}$ y Tácito se burlan del final trágico y de la apoteosis de Claudio, pues parece ser que murió envenenado. Del mismo modo que el emperador se ha convertido en dios, Pablo interpreta la muerte de Jesús: también Jesús llegó al poder mediante una muerte violenta y se convirtió en hijo de Dios, en verdadero rey ${ }^{77}$. Para Pablo, Jesús es lo que el princeps romano reivindica ser: representante de la humanidad, reconciliador y soberano del mundo. Por eso, se propaga y extiende el evangelio a toda nación $(1,5)$.

En otro pasaje de la carta (Rom 10,4), Pablo proclama a Cristo como telos tou nomou, es decir, su persona significa el fin del sistema estatal normativo y autoritativo romano, así como la pretensión de la divinidad del emperador. En Rom 15, Georgi cree ver alusiones a Alejandro Magno. Como en el caso Alejandro, también la misión de Jesús es interrumpida. Pero Pablo lleva a cumplimiento la obra incompleta, no sólo de Jesús, sino también de Alejandro. Esto acontece gracias a la ayuda de los seguidores del crucificado en la capital del imperio.

Si Pablo estaba en contra del imperio romano, ¿cómo es que encontramos un texto como Rom 13,1-7? Este es uno de los textos que mayor dificultad plantea a los estudiosos del Politics Group. Para este grupo de autores, sorprende y choca que Pablo pudiera hablar tan positivamente de Roma, olvidándose de la brutalidad que caracterizaba a los romanos. Teniendo en consideración otros textos paulinos, donde expresa su visión más crítica contra las autoridades (1Tes 5,3-11; 1Cor 15,24-26), este texto siempre ha provocado infinidad de interpretaciones, comenzando por considerarlo una interpolación. Asimismo, se ha intentado determinar las circunstancias históricas que provocaron esta admonición paulina. Aunque todas las hipótesis son muy sugerentes, según estos autores, ninguna es plenamente convincente ${ }^{78}$.

Neil Elliot ${ }^{79}$ propone buscar no tanto la situación histórica, sino más bien un "contexto de vida". Teniendo en cuenta la situación de los judíos en Alejandría (año 41 d.C) y los privilegios que gozaban los judíos en Roma, no es de extrañar la existencia de ciertos sentimientos antisemitas.

${ }^{76}$ Cf. la obra de Séneca, Apocolocyntosis; Dio Cassio, LX 35,2ss; Tácito, Ann 13,3-4.

77 Para las implicaciones políticas de este texto, cf. G. THEISSEN, Auferstehungsbotschaft und Zeitgeschichte. Über einige politische Anspielungen im ersten Kapitel des Römerbriefs, en: Auferstehung hat einen Namen. FS für H.-J. Venetz, Luzern 1998, 58-67; Jacob Tauben, Politische Theologie 23-26.

78 Cf. las diversas interpretaciones del pasaje en David Álvarez Cineira, Die Religionspolitik 395-404.

${ }^{79}$ NeIL ELLIOT, Liberating 223. 
La curiosa combinación en 13,1-7 del pragmatismo $(13,2.4 \mathrm{~b})$ y del idealismo respecto a las autoridades (4a.6), no significa proponer teorías filosóficas sobre la esencia del estado. Pablo únicamente pretende evitar que los miembros de la ekklesia provoquen disturbios y problemas callejeros. Desea que su auditorio olvide los resentimientos personales. En su lugar, pretende impulsar la compasión mutua y que los cristianos anhelen el bien común.

Elliot coloca este párrafo en el contexto de la propaganda imperial y específicamente contra la entronización de Nerón en el año 5480 . El objetivo de Pablo consistía en que los judeocristianos, que habían regresado a Roma, necesitaban una protección frente a la calumnia de que no pagaban sus impuestos. Ya que una confrontación con el poder estatal no tendría sentido, el apóstol les exhorta a aceptar las circunstancias actuales y pagar los impuestos. El consejo paulino, por tanto, respondería a cuestiones tácticas.

En otras palabras, dado que las instituciones humanas habían sido encargadas por Dios en beneficio de los administrados, "por tanto, uno debía someterse no solo por consideración de la ira divina, sino también por motivo de conciencia" $(13,5)$. La autoridad humana era limitada y relativa. Si está instituida por Dios y sirve como "un ministro" de Dios, entonces está sujeta a Dios y no puede arrogarse el honor que corresponde a Dios. Por consiguiente, la exhortación de Pablo a la sumisión no se puede entender como una sumisión ciega a cualquier poder. En el pensamiento paulino podían estar otras dos ideas implícitas. La primera sería la instrucción de Jeremías a los exiliados de "buscar el bien" de la ciudad pagana, allí donde se encontraran (Jer 29,7). En Rom 13,3 tendríamos el mismo principio en términos de euergetismo. La frase "hacer el bien" aparece estar relacionada con las obras sociales de beneficencia y el servicio público. La segunda cuestión eran los impuestos (Tácito, Annales 13,50s). Habiendo exhortado a los creyentes de Roma a adoptar la conducta apropiada hacia los de dentro y hacia los conciudadanos no cristianos, Pablo juega con la noción de lo que se "debe" hacer para llegar otra vez al punto de partida. Pagar los impuestos justos y rendir el honor apropiado, son parte del amor $(13,8-10)^{81}$.

80 NeIl Elliot, Romans 13:1-7 in the Context of the Cross, en: Richard A. Horsley (ed.), Paul 184-204.

81 Christopher BRYAN, Render to Caesar 81s: "The laws of the Empire are to be obeyed and Christians are to seek to be good citizens, not because life never changes and God's kingdom is only a dream but precisely because the new age is already beginning. Already believers are like those who stretch and blink and prepare to begin a new day $(13,12)$. Still they are exiles, but they know that the end of their exile is near". 


\subsection{La paz y justicia}

El tema de la paz y la justicia viene tratado en 1Tes 5,2s. Klaus Wengst $^{82}$ ve en este pasaje un factor de propaganda romana: Roma garantiza pax et securitas ${ }^{83}$, tanto en las relaciones internas como externas. Helmut Koester también apoya una interpretación política del texto. En medio de un pasaje con tintes apocalípticos, Pablo utiliza una expresión no-apocalíptica, no bíblica. La alusión a Jer 6,14, que frecuentemente se aduce, no es correcta. Pablo diría claramente que el eschaton cercano acabará con la falsa paz y seguridad que ofrecía el sistema romano. Con ello, Pablo critica abiertamente la ideología tan extendida, según la cual Roma es custodio y garante de la pax y de la seguritas. La edad de oro de Roma ha traído paz y seguridad a Tesalónica. Esta paz y seguridad era la que prometía Roma a sus colonias o provincias. Por el contrario, Pablo dice que existe una catástrofe inminente que amenaza la serenidad julio-claudiana y abiertamente se mofa de la complạcencia imperial. El apóstol afirma claramente en 1 Tes 5,3 que toda esa propaganda imperial ha sido una farsa. Es la edad de oro de Dios la que ya ha comenzado, y culminará pronto con la "llegada" (en griego, parusía: 1 Tes 2,19; 3,13; 4,15; 5,23) no de un divino Claudio, sino de un divino Cristo.

\section{Pablo y sus comunidades. Una sociedad alternativa}

Pablo no piensa en sus comunidades en términos religiosos. Los préstamos cúlticos de los clubs socio-religiosos greco-romanos (thiasos y eranos) y el lenguaje cultual greco-romano están ausentes. Tampoco se puede afirmar que las comunidades paulinas fueran modeladas conforme a las asociaciones o collegia ${ }^{84}$. El concepto principal que Pablo usa para referirse al movimiento de los seguidores de Jesús como un todo y a las comunidades locales en particular, es el término "ekklesia". Esta denomina-

82 KlaUs Wengst, Pax Romana 109ss.

83 John Dominic Crossan - Jonathan L. ReEd, In Search of Paul xi: "The Roman Empire was based on the common principle of pace through victory or, more fully, on a faith in the sequence of piety, war, victory and peace. Paul was a Jewish visionary following in Jesus' footsteps, and they both claimed that the Kingdom of God was Roman normalcy with a vision of peace though justice or, more fully, with a faith in the sequence of covenant, nonviolence, justice and peace".

${ }^{84}$ Cf. Richard S.Ascough, Paul's Macedonian Associations. The Social Context of Philippians and 1 Thessalonians (WUNT II 168), Mohr Siebeck, Tübingen 2003; Philip A. Harland, Associations, Synagogues, and Congregations. Claiming a Place in Ancient Mediterra- 
ción designaba en el imperio romano de Oriente la asamblea de ciudadanos de una polis griega. Pablo entendió la ekklesia de Tesalónica o Corinto no como una "comunidad cúltica", sino como la asamblea política de los seguidores de Cristo, en contraposición y "competencia" con la asamblea oficial de la ciudad (1Tes 1,$1 ; 1$ Cor 11,$18 ; 16,1 ; 16,19 ; 2$ Cor 8,$1 ;$ Gal 1,2; 1 Tes 2,14). El apóstol pensó que relacionando entre sí las asambleas locales, estaba construyendo un movimiento político-religioso interurbano de ámbito y dimensiones internacionales. Las ekklesias paulinas serían, por tanto, comunidades locales que se presentan como una sociedad alternativa al orden imperial romano. Éstas estaban enraizadas en la historia de Israel, en oposición a la pax romana. Cuando Pablo habla de la asamblea de Dios, se está refiriendo a las asambleas de Yahve, y Dios ha guiado la historia a través de Israel, no de Roma. Las promesas hechas a Abraham de que todos los pueblos recibirán la bendición, se han cumplido en la crucifixión de Jesús y en su exaltación al cielo. Estas ideas están explícitas en Gal, 1 Cor y Rom, e implícitas en 1Tes, Filp y en secciones de 2 Cor. La expresión más clara de esta postura aparece en 1 Tes 5,1-11 (cf. Helmut Koester), donde los tesalonicenses están involucrados defensivamente en una guerra virtual con el imperio, defendiéndose con la metafórica "coraza de la fe y el amor, y el casco de la esperanza de la salvación". La integración en la sociedad era lo último que Pablo habría deseado para sus comunidades. A los corintios, por ejemplo, les insiste en que no deben cooperar con los tribunales oficiales; de hecho, los santos juzgarán el mundo (1Cor 6,1-6). De forma similar, les prohibió participar en los banquetes celebrados en los templos en honor de los dioses (1Cor 10,14-22). Su principio general fue que, aunque estaban abiertos a la sociedad para reclutar miembros para la nueva comunidad, los corintios (y probablemente otras comunidades) tenían que vivir como "si no tuvieran tratos con el mundo" (1Cor 7,29-31). Frente a este mundo, Pablo insiste en que "nuestra politeuma" está en el cielo y de allí esperamos un Soter (Filp $3,20)^{85}$. Viviendo en una sociedad hostil, Pablo exhorta a sus comunidades a ser solidarias entre sí y a vivir en concordia y armonía.

nean Society, Fortress Press, Minneapolis, 2003; John Kloppenborg - Stephen G. Wilson (ed.), Voluntary Associations in the Greaco-Roman World, Routledge, London - New Cork 1996.

85 Otro texto considerado como anti-imperial es Filp 3,18-19. Pero el lenguaje que encontramos aquí es el típico de la polémica religiosa judía, una retórica de culpa aplicada a ésos que el autor considera apóstatas. Así también lo encontramos en Filón, en 3 Mac y en los testamentos de los Doce Patriarcas (Filón, de Virt. 182, 3 Macc 7,11; Testamento de Moisés 7,4; Rom 16,18). Por eso, resultaría extraño que aplicara este lenguaje a los paganos. Es 
Las comunidades-ekklesia que Pablo funda, constituyen una sociedad alternativa internacional basada en comunidades igualitarias locales ('asambleas'). Horsley ${ }^{86}$ analiza la comunidad de Corinto y el sistema de patronazgo avocado al fracaso $(15,24-28)$ y extrapola sus conclusiones a otras comunidades. Describe alguna de las características de las comunidades paulinas: 1) Se reúnen en comunidades domésticas, y forman una red de células de un movimiento social que está surgiendo;2) Según 1 Cor 5-6, las comunidades deben regular sus problemas dentro de sí mismas, sin acudir a los tribunales ordinarios y con una estricta disciplina interna. 3) También 1Cor 8-10 propone la retirada de la sociedad; el apóstol invita a sus comunidades a ser solidarias en el ámbito político-religioso frente a una sociedad dominante que se reunía en banquetes dedicados a los dioses. 4) Pablo renuncia a la ayuda financiera, porque intenta evitar las relaciones cliente-patrón en Corinto (1Cor 9,1-18; 2Cor 11,7-11). 5) La colecta indica una red de grupos con una dimensión política-económica internacional. Finalmente, la retórica de 1Cor tiene como objetivo crear comunidades independientes de la sociedad.

Por consiguiente, podríamos definir estas comunidades como células diseminadas, leales a Jesús como Señor, que formaban colonias dentro del imperio, es decir, pequeños grupos subversivos cuando son vistos desde la óptica del emperador. Pero vistos desde la perspectiva judía, son un anticipo del tiempo final, cuando la tierra sea recubierta con la gloria del Dios de Abraham y las naciones se unan a Israel para cantar las alabanzas de Dios (Rom 15,7-13). Este contra-imperio nunca puede ser meramente crítico, ni subversivo, sino que en él debe reinar la justicia, la paz y la unidad más allá de las tradicionales barreras culturales y raciales ${ }^{87}$.

$\mathrm{El}$ intercambio personal recíproco pero asimétrico (vertical) de bienes y servicios en las relaciones cliente-patrón está en oposición diametral a las asociaciones horizontales y a la reciprocidad existente en el parentes-

probable que aquí tenga en mente a los mismos oponentes que aparecen en 3,1b-4a y que tienen que ver algo con el judaísmo.

${ }^{86}$ RiCHARD A. HoRsLEy, Paul's Assembly in Corinth: An Alternative Society, en: Daniel N. Showalter - Steven J. Friesen (ed.), Urban Religion in Roman Corinth. Interdisciplinary Approaches (Harvard Theological Studies 53), Harvard University Press, Cambridge Massachusetts 2005, 371-395, "Paul did not found a religion, much less convert from one religion to another. Paul rather helped spearhead what can be understood as an international anti-imperial movement of communities that he saw as constituting an alternative society of justice, co-operation, and mutuality opposed to the Roman imperial order, which was finally being terminated through God's action in Christ" (394).

87 N.T. Wright, Paul's Gospel and Caesar's Empire 182s. N.T. Wright, Paul. In Fresh Perspective, Fortress Press, Minneapolis 2005, 59-79. 
co y en las sociedades rurales. Pablo se opone a los modelos dominantes de las relaciones sociales en la sociedad romana imperial. Gal 3,28 simboliza la superación de las divisiones dentro de la sociedad dominante, caracterizada ésta por la familia patriarcal donde se mantenía la esclavitud. El apóstol propone unas relaciones sociales relativamente igualitarias, en contraposición a las jerárquicas ${ }^{88}$.

En contra del sistema económico del patronazgo imperial, Pablo organiza una "colecta" para los pobres de Jerusalén (Rom 15,25-28; 1Cor $16,1-4 ; 2$ Cor $8 ; 9)$. Con ella, propagaba como judío la unidad escatológica y universal de judíos y paganos ${ }^{89}$. Según Sze-Kar Wan ${ }^{90}$, el apóstol entiende que los gentiles traen regalos a Jerusalén como signo de que la prosperidad proviene de Dios y la generosidad gentil hacia Jerusalén redunda para gloria de Dios, lo cual pondría en cuestionamiento el sistema mismo del patronazgo imperial91.

Por supuesto, Pablo esperaba el final inminente de esta "generación perversa", de este "mundo pasajero". Mientras tanto, se preocupó por formar "comunidades" en las ciudades del imperio oriental como grupos alternativos a la sociedad existente. Estas comunidades debían mantener la solidaridad en la batalla contra el orden imperial dominante hasta que Cristo someta todo (Filp 3,20-21). A pesar de lo impreciso que fue sobre las formas sociales en el "reino de Dios", Pablo estaba construyendo una sociedad alternativa internacional basada en las comunidades igualitarias locales. El apóstol no insta a sus comunidades a integrarse en los foros políticos, campo exclusivo de los poderosos, para cambiar desde allí las estructuras, sino que sus comunidades han de formar una sociedad alternativa, donde deben vivir en anticipación el triunfo de la llegada de Dios.

88 Elisabeth Schüssler Fiorenza, The Praxis of Coequal Discipleship, en: Richard A. Horsley (ed.), Paul and Empire 224-241.

${ }^{89}$ También D. Callahan, Paul, Ekklesia, and Emancipation in Corinth. A Coda on Liberation Theology, en, Richard A. Horsley (ed.), Paul and Politics 216-223, afirma en su artículo sobre Corinto que la colecta para los pobres en Jerusalén propagaba una reciprocidad internacional, que sería única o singular en el imperio romano.

${ }^{90}$ Szw-kar Wan, Collection for the Saints as Anticolonial Act: Implications of Paul's Ethnic Reconstruction, en: Richard A. Horsley (ed.), Paul and Politics 191-215.

91 Antoinette Clark Wire, Response. Paul and Those Outside Power, en: RICHARD A. Horsley (ed.), Paul and Politics 224-226: "But is Paul's primary intent in making the collection to exalt God's universal glory over Rome's? The collection seems to me to have at least another more immediate purpose, namely to vindicate one Judaism in the eyes of another. Is Paul not working, first and foremost, to vindicate his messianic mission to the Gentiles in the eyes of "the saints in Judea" (messianic Jews) and "unbelievers" (nonmessianic Jews), who serve despite Paul as the measure of Jewish identity (Rom 15,30-32)? Yet I have not been convinced that Paul's collection is anti-imperial except in the broadest sense that Jewish hopes and claims ultimately conflict with imperial claims". 


\section{Anotaciones críticas}

Sin lugar a dudas, es digno de mención que dentro de las publicaciones de las sesiones y artículos del Politics Group se hayan invitado a personas ajenas al grupo. Simon R.F. Price, experto en historia antigua, realiza algunas precisiones sobre el contexto político y sobre el Pablo subversivo. En cuanto al contexto político, los nuevos estudios consideran al imperio no simplemente como una estructura impuesta por Roma, sino como resultado de una serie de elecciones y negociaciones realizadas entre súbditos y gobernantes, dado que en el siglo I d.C. no existía una alternativa realista al imperio romano en el mundo griego. Para entender una pretendida figura provincial subversiva, es necesaria colocarla en el contexto de "subversión" dentro del imperio romano. La tendencia de las investigaciones más modernas sobre este periodo hace que esta supuesta subversión sea muy difícil de aceptar. Normalmente se subraya más la felicidad consensual, sin conceder mucha importancia a la perspectiva de los de fuera. El imperio era una unidad masiva con gran diversidad. Las actitudes de esos que estaban al margen de Roma es muy difícil de determinar, pero es claro que no sólo los judíos y cristianos eran los únicos descontentos del imperio. Es difícil encontrar ejemplos articulados y organizados de "enemigos del poder romano", pero las tradiciones cúlticas locales llegaron a ser el verdadero terreno abonado para la oposición al poder romano. Del contexto romano del imperio, Price concluye que es un error presuponer que el contexto en el que Pablo debe ser situado es el de Roma. El mundo de la ideología de la corte imperial augustea está muy alejado del mundo de las ciudades orientales del imperio romano. Existe un gran abismo entre el mundo de Augusto y el mundo de Pablo. La importancia de los cultos provinciales o cívicos ayuda a entender cómo Pablo buscó situar su teología-cristología en distinción a la ideología del poder dominante.

Otro aspecto relevante eran las relaciones patrón-cliente. ¿Pretendía Pablo modificar el sistema de relaciones basadas en el patronazgo y en la recomendación? El sistema de "recomendación" muestra la diferencia entre las clases altas y bajas, sin necesidad de suponer que Pablo intentara subvertir y cambiar esa práctica ${ }^{92}$. La crítica paulina de la depravación gentil implica una crítica sobre parte de las bases ideológicas del poder

92 Personalmente, no creo que podamos hacer de Pablo un líder sindicalista que intentara cambiar el sistema de relaciones laborales por considerarlo injusto y defender los derechos de los trabajadores. Cosa distinta es que él no quisiera entrar en la dinámica del 
imperial (los emperadores son aceptables porque son virtuosos), pero esta implicación no fue pretendida necesariamente por el autor ni reconocida por la audiencia. El contexto correcto donde debemos situar este argumento de Pablo es en la polémica greco-romana contra las pasiones sexuales. La crítica cultural paulina es política, pero no de forma restringida ${ }^{93}$. Los textos paulinos que dejan vislumbrar aspectos políticos, no están dirigidos contra Roma misma, sino contra las estructuras locales de poder. Las críticas que encontramos en las cartas del apóstol no eran estrictamente políticas sino que englobaban amplios aspectos de los valores sociales y religiosos locales.

Antoinette Clark Wire ${ }^{94}$ cuestiona la visión que presenta Horsley sobre la función de la retórica paulina frente a la retórica imperial. No está tan claro que la retórica anti-imperial caracterizara el discurso paulino en 1 Cor y lo distinga de esos a quienes intenta persuadir. Las indicaciones referidas a los poderes de este mundo, que se encuentran en el marco de la carta $(1$ Cor 2,$8 ; 15,24)$, pudieran referirse a tradiciones que tenía en común con los cristianos de Corinto. ¿A quién intenta convencer Pablo? No a los ricos, ni a los sabios, que eran pocos. Sino que habla a un conglomerado de personas urbanas, cuyos miembros no tienen status o tienen un status muy bajo, y Pablo espera que encuentren en su patronazgo paternal una ayuda o, al menos, una buena disciplina. Es decir, Pablo utiliza la misma retórica persuasiva que se utilizaba en Corinto, simplemente que con el objetivo de ganar adeptos para su causa.

En su respuesta a Wan y Callahan, Calvin Roetzel menciona algunos de los problemas fundamentales de las propuestas referidas. Si Pablo esperaba un final tan cercano, ¿qué es lo que le llevó a organizar una acción anti-imperial como la colecta? Del mismo modo, cuando el tiempo pasa pronto y el esquema de este mundo deja de tener valor y desaparezca (1Cr 7,29.31), entonces toda revolución se convertirá en una estrategia innecesaria. Esto también se ha de aplicar a la presumible compra de esclavos mediante la comunidad (como Callahan presupone en 1Cor 7,21-23).

patronazgo (en Corinto) por las contraprestaciones negativas que tendría para su libertad a la hora de predicar.

93 Simon R.F. Price, Response, en: Richard A. Horsley (ed.), Paul and the Roman Imperial Order 183.

94 Antoinette Clark Wire, Response. The Politics of the Assembly in Corinth, en: Richard A. Horsley (ed.), Paul and Politics 127: "I think Horsley greatly oversimplifies and even falsifies the picture to present Paul as the champion of what is anti-imperial and antielite in these urban churches. We have yet further steps to take to emerge fully from the Christian tradition of making the apostle the measure of virtue as we see it and the Corinthians the dark foil for its display". 
El lema sería más bien: "Resistid, aguantad, pues la salvación está llegando" 95 .

Jennifer Wrigth Knust ${ }^{96}$ considera que la crítica de Pablo a la sociedad envuelta en lujuria y promiscuidad es una adaptación de la crítica común del discurso cultural greco-romano. La ideología imperial romana pretendía hacer creer que Augusto y sus sucesores habían restablecido la moralidad pública. De hecho, el mismo emperador, en total control de sus propias pasiones, domeñó el vicio y la inmoralidad en el ámbito público mediante el cumplimiento de la ley y de las costumbres. En este contexto imperial, la afirmación paulina de que la sociedad en general está llena de fornicación, habría sido entendida como una crítica dirigida al emperador. $\mathrm{Al}$ adaptar esta crítica común de la inmoralidad sexual para oponerse al poder imperial, sin embargo, Pablo reinscribe en su propio discurso antiimperial los presupuestos jerárquicos del sexo, de género y de la esclavitud implícitos en esa crítica.

\section{Valoración y aportaciones}

Otros estudiosos ya habían analizado anteriormente a Pablo dentro del contexto greco-romano, pero sólo intentaban ubicarlo en su contexto social o histórico, sin destacar la confrontación entre Pablo y el mundo pagano al que se dirigía. Sin lugar a dudas, R.A. Horsley con su libro Paul and Empire. Religión and Power in Roman Imperial Society ${ }^{97}$ ha abierto nuevos caminos de investigación sobre Pablo dignos de ser tenidos en consideración. La repercusión del "Paul and the Politics Group" ha sido amplia en ambientes americanos. Estos estudios se proponen examinar al Pablo político, abogando que negando esta dimensión del pensamiento paulino ${ }^{98}$, se descontextualiza y "domestica" al apóstol y hace que las lec-

95 Calvin J. Roetzel, Response: How Anti-Imperial Was the Collection and How Emancipatory Was Paul's Project?, en: Richard A. Horsley (ed.), Paul and Politics 227-230.

96 Jennifer Wright Knust, Paul and the Politics of Virtue and Vice, en: Richard A. Horsley (ed.), Paul and the Roman Imperial Order 155-173.

97 Otro libro en esa misma dirección: NEIL ELLIOTT, Liberating Paul. Cf. el comentario que hace sobre este libro Bruno Blumenfeld, The Political Paul 396: "Elliott's 1994 study on the politics of Paul, attempts to make Paul not only palatable but even pertinent to liberation theology. The provocative work is packed with contradictions and is better suited to a discourse on oppression and liberation, a modern political theme, than to one on the Pauline political concerns".

98 Esta idea la expresa también NoRMAN A. BECK, Anti-Roman Cryptograms in the New Testament. Symbolic Messages of Hope and Liberation (The Westminster College Li- 
turas de sus cartas sean parciales. La teología paulina no puede ser totalmente comprendida sin el conocimiento del contexto y la dimensión política ${ }^{99}$. La pretensión de Pablo es integrar la muerte de Jesús en un plan político. Para ello reelabora los estereotipos políticos comunes de su tiempo y, al mantener el carácter individual y egoísta de la salvación, produce una soteriología que es colectiva y política, sin fijarse tanto en los preceptos morales.

A pesar de lo sugerentes que son muchas de las lecturas propuestas sobre diversos textos de las cartas paulinas, creemos que diversas afirmaciones del grupo merecen ser matizadas. Según Horsley y otros estudiosos, aplicando la clave del lenguaje imperial, Pablo estaba convirtiendo a Jesús en la alternativa política del imperio o en el verdadero emperador del mundo ${ }^{100}$. Pero ¿realmente pretendía Pablo eso? ¿Desea el mismo Pablo ser entendido como anti-imperial, por tanto habría que tomar la formulación en un sentido intencional-final? ¿O hay que pensar sólo en una posible recepción del lector de aquella época (y por tanto en un sentido consecutivo)? Aquí, una vez más, nos movemos en terreno poco seguro y resbaladizo. La frase clave es "anti-imperial" y ¿qué se entiende por "anti-imperial"?. La opinión propuesta por Horsley es que el empleo de la retórica imperial significaba estar en confrontación con el imperio. ¿Pero fue realmente así? El investigador americano piensa que el apóstol pretendió conscientemente esa confrontación. El conjunto de la teología paulina está en confrontación con determinados hechos políticos y sociales, que hacen ineludible una orientación anti-imperial. Esto significa que las cartas paulinas no fueron concebidas sólo para ser leídas en ámbito cristiano y dentro de la iglesia, sino como documentos para ser difundidos en un contexto amplio. ¿Qué entendería un romano o un griego no fami-

brary of Biblical Symbolism 1), Peter Lang, New York 1997, 52: "Paul and the others made their writings appear to be much less 'political' than they actually were. By making their writings appear to be entirely 'religious', they protected themselves, their intended readers, and the cryptograms from detection by their enemies" (p. 53). Pero no cree que Pablo fuera un rebelde militar contra el poder romano. "He was not an insurrectionist" (p. 58), aunque el uso de los criptogramas (satán, demonio, tentador, dominio de las tinieblas) denota que Pablo estaba interesado en la liberación de la opresión política del estado romano (p. 92).

99 Cf. BRuno Blumenfeld, The Political Paul 13: "By grounding Pauline Christianity in Hellenistic political theory in general, and in the theory of Hellenistic monarchy in particular, the work also provides a new explanation for the success of Christianity". "I would call Paul a revolutionary, if he were not so much of a reactionary. Paul erases ethnic, social and political binaries: Jew-Greek, Greek-barbarian, free-slave, ruler-ruled" (291s).

100 HorsLeY, Jesus and Empire 134; John Dominic Crossan - Jonathan L. Reed, In Search of Paul, 10-14. 
liarizado con las tradiciones cristianas o judías de las cartas paulinas? Sin lugar a dudas, que les debía parecer chino.

Tras leer los libros publicados por Horsley, se pueden obtener muchas imágenes del apóstol. La primera que nos viene a la mente es que nos hallamos ante un héroe anticolonial, al estilo de Gandhi, o un Simón Bolívar o Zapata desarmado. Nos hallamos ante un rebelde romano dentro del mismo imperio romano ${ }^{101}$. ¿Pero realmente era Pablo un romano antiromano? ¿un antisistema? ¿un líder sindicalista que buscaba abolir el sistema injusto del patronazgo? ¿el primer teólogo de la liberación o el primer crítico de la globalización? ¿Eran las comunidades paulinas el primer movimiento antisistema y antiglobalización que conocemos en la historia? Todas éstas son categorías políticas modernas que difícilmente se pueden aplicar al siglo I d.C. Habría sido totalmente una irresponsabilidad de Pablo promover una insurrección política contra el poder político, y más en el corazón del imperio, Roma. Las autoridades lo habrían apresado y ejecutado inmediatamente. Al mismo tiempo, habría puesto en peligro la vida de quienes estaban vinculados a él. En el siglo I no existía un estado de derecho democrático y justo, donde uno pudiera expresar libremente sus ideas políticas contrarias al principado sin ser inmediatamente ejecutado.

Pablo estaba interesado en la situación política del ímperio, pero sus cartas indican que primeramente fue un líder religioso y no un revolucionario político, del mismo modo que Jesús fue una figura religiosa más que un líder político. El apóstol escribió fundamentalmente sobre Dios y sobre Jesús, Cristo y Señor resucitado, y no panfletos políticos contra el emperador o contra Roma. Es verdad que la designación de Jesús como Cristo y Señor resucitado tenía dimensiones religiosas y políticas, ya que coloca a los cristianos frente a las pretensiones del emperador: ser Señor del universo. Pero Pablo acepta la autoridad del Estado romano en el ámbito político, en tanto en cuanto la autoridad no pretenda ser el fundamento último religioso. Y sabemos que los emperadores romanos coetáneos de Pablo (excepción hecha de Calígula) no exigieron el culto al emperador.

Es fácil destacar la confrontación de Pablo con algunos aspectos de su mundo greco-romano. Lo que constatamos a lo largo de sus escritos, sin embargo, es el hecho de que él se opuso al paganismo en todas sus formas.

101 Sobre los rebeldes dentro y fuera del imperio romano, cf. BRENT D. SHAW, Rebels and Outsiders, en: The Cambridge Ancient History. XI: The High Empire A.D. 70-192, Cambridge University Press, Cambridge 2000, 361-403. 
No se opone al imperio principalmente porque éste fuera un imperio, con todos los elementos desagradables que hemos aprendido a asociar a la palabra, sino porque la ideología imperial reclamaba una posición y unos honores divinos que únicamente pertenecían a Dios. Esto no quiere decir que Pablo aprobara eso que criticamos; sólo que sus sensibilidades políticas fueron dirigidas por sus preocupaciones teológicas, no viceversa ${ }^{102}$.

Pablo criticó a la superpotencia romana, una crítica que estaba en conformidad con la tradición bíblica y profética, es decir, con su herencia judía. Su base se encuentra en la afirmación profética "el señor es nuestro juez, el Señor es nuestro gobernante, el Señor es nuestro rey, él nos salvará" (Isa 33,22). Lo que hace con el culto al emperador, proviene directamente de lo que Isaías hizo con el culto de Babilonia, que a su vez hace referencia al rechazo deuteronomista de todo paganismo a favor del monoteísmo. De este modo, la tradición bíblica desafía todas las estructuras humanas de poder, no para desmantelarlas ni reemplazarlas con otras estructuras de poder, sino para confrontarlas coherentemente con la verdad acerca de su origen y objetivo ${ }^{103}$.

La proclamación de Pablo es, por tanto, política, de la misma manera que la tradición bíblica es "política". Esto es afirmar que existe Uno que está por encima de todo poder terrenal. La proclamación de la autoridad universal de Cristo tiene sus consecuencias sociales y políticas. Es un desafío para los gobernantes para que comprendan la base de su autoridad y una llamada a buscar la justicia de Dios para los súbditos. Pero eso, en sí mismo, no significa el rechazo de los gobernantes. La proclamación de Pablo no es "política" en la medida en que se entienda por "política" un intento por reemplazar o reorganizar las estructuras específicas, negándose a estar sometido a la autoridad de un Estado o soberanos concretos.

No existen evidencias para afirmar que Pablo -o los cristianos de Filipos- rechazaron la institución del Estado romano como tal, o que desearan reemplazarlo por alguna otra institución política humana ${ }^{104}$. Un ejemplo claro sería la carta a los Filipenses, escrita desde una prisión romana, en un momento que realmente tenía razones suficientes para criti-

102 N.T. WRIGHT, Paul's Gospel and Caesar's Empire (160-183).

103 Christopher BRYAN, Render to Caesar. Jesus, The Early Church, and the Roman Superpower, Oxford University Press, Oxford 2005, 9. Varias de las críticas aquí expresadas provienen de su libro.

104 PETER OAKes, Re-mapping the Universe: Paul and the Emperor in 1 Thessalonians and Philippians, en: JSNT 27 (2005) 301-322, examina los textos clave de 1 Tes y Filipenses, donde se pudiera detectar el culto romano y la ideología. Supone que los textos sí que implican conflicto entre el cristianismo y Roma, pero también afirma que los testimonios no 
car el poderío romano (1,12-26). En Filp 3,20-4,1 encontramos una imagen de Cristo como salvador que llama la atención. El origen de esta imagen es claro. Surge de la noción de la ciudadanía romana (politeuma) bajo un empcrador que llega desde Roma como "salvador" para asistir y defender una comunidad romana -posiblemente a un ejército romano o colonia romana- que se encuentra en dificultad. Así, el emperador Claudio "vino en ayuda" de sus legiones bajo la dirección de Aulas Plautius que estaban experimentando dificultades durante la campaña británica en el 43 d.C. (Dión Cassio, 60,22; ILS 216). Esto se entendería perfectamente en Filipos, una colonia romana. Algunos miembros de la comunidad cristiana poseerían la ciudadanía, ciudadanía que "nunca era irrelevante" con relación a su posición en la sociedad. La idea de Pablo es la siguiente: Como cristiano, el filipense posee la "ciudadanía" bajo un "salvador" mucho mayor que Augusto. Tal "salvador" puede sostener y justificar a sus seguidores en Filipos, no solamente frente a los enemigos de Roma, sino incluso frente al pecado y a la muerte.

¿Está diciendo aquí Pablo que como eran miembros de la iglesia, entonces no pueden ser miembros del Estado romano (Filp 3,20-21) ${ }^{105}$ ? Eso no lo dice Pablo. Si el apóstol está diciendo que los cristianos de Filipos, incluso los que poseen la ciudadanía romana, no podían considerarse sujetos a Roma porque ahora eran cristianos -entonces tenemos que considerar por la misma razón, que ya que los cristianos son miembros de la "casa de Dios", entonces ya no podrían pertenecer a ninguna otra casa humana ordinaria. Tal afirmación no tendría sentido, ni tendría en cuenta la metáfora. Los cristianos no son literalmente ciudadanos del cielo (el cual no es literalmente un estado o una realidad) como tampoco son literalmente hijos de Dios (quien no es literalmente un padre), ni la iglesia es $l i$ teralmente una casa.

Pienso que Pablo a veces utilizó deliberadamente una retórica proveniente de la retórica del imperio romano. Pero, hay que examinar en cada caso concreto. Todos tuvieron que utilizar un vocabulario y los conceptos para hablar de las cosas que consideraron como sagradas, y todos tuvieron que utilizar más o menos la misma terminología y semejantes

apoyan la teoría de que Pablo estuviera escribiendo una polémica anti-romana, oponiéndose al culto romano o expresando el deseo de la caída de Roma. El conflicto surge más por las incompatibilidades inherentes y contrastando las demandas del evangelio comparándolo con la ideología romana: dos "mapas" del universo muy diferenciados.

105 Según PETER OAKES, Filp 3,20-21 significa que "the Philippian Christians belong to another state. Not only that, but this is the only state to which they belong...". 
conceptos. De ahí, la existencia de paralelismos, de contactos en la terminología ${ }^{106}$.

¿Hasta qué punto eran las comunidades cristianas alternativas a las ciudades imperiales? La distinción entre la ekklesia y el sistema político de Roma no es de interrupción ni polarización sino de continuidad y afinidad. La polis cristiana no se opone a la cultura ni a la política de Roma enfrentando el ámbito privado al público, el personal al colectivo, o el familiar al oficial y ceremonial. La cristiandad, tal y como se desarrolló gracias a personas como Pablo, se aprovechó tanto de la polis como del imperio ${ }^{107}$. En la situación política concreta de Roma (Rom 13), las comunidades debieron organizar sus relaciones hacia fuera, de tal forma que no se distanciaran ni rompieran con el código aceptable de comportamiento, sino que pudieran vivir en él. No existía otra alternativa posible, por lo que la lealtad política era la actitud más adecuada. Pablo renunció a toda argumentación cristiana para justificar dicha actitud y optó por ser pragmático: los cristianos debían mostrarse como otros ciudadanos más en el ámbito social108.

Un aspecto interesante que hecho en falta en los estudios del "Politics Group" es la cuestión de la ciudadanía romana de Pablo. Hablan de una "supuesta" ciudadanía romana. Sin lugar a dudas, que no es lo mismo que un persona sometida o esclava del imperio romano muestre una actitud anti-imperial que lo haga un ciudadano romano, un privilegiado. Sería significativo que Pablo, como ciudadano romano, con todo lo que ello conllevaba de beneficios y privilegios, hubiera tenido una actitud tan rebelde y beligerante contra su propio "Estado". Como ciudadano debería haber mostrado cierta lealtad y respeto al emperador ${ }^{109}$. En caso de haber poseído la ciudadanía romana y con esta postura anti-imperial, es lógico que el

106 Dominique Cuss, Imperial Cult 52: "Imperial titles are identical with those titles which are applied by the Christian to Christ... There is obviously much that bears a strong resemblance, and there are many common traits between the emperor-cult and the worship given to the Christian God through Christ... Many of the Christian expressions have, it is true, their roots in Jewish terminology, but the pagan invocations must have been wellknown to the first century converts". Esta autora considera que el lenguaje usado no pretendía ser un contraste deliberado del culto imperial y las ideas cristianas de Cristo (p. 141).

107 Bruno Blumenfeld, The Political Paul 408.

108 STEFAN SCHREIBER, “Imperium Romanum” 164: „In der konkreten Situation -so signalisierte das hidden transcript -ist es nicht Aufgabe (und Möglichkeit) der christlichen Gemeinden in Rom, die politischen Verhältnisse zu korregieren oder zu wandeln, sondern dies bleibt allein der Macht Christi vorbehalten“ (164).

109 La mayor parte de los estudiosos considera que Pablo era ciudadano romano, y piensan que era un ciudadano leal al estado romano, cf. DoMINIQUE Cuss, Imperial Cult 3944. No considero que Pablo poseyera la ciudadanía romana, un privilegio reservado para 
apóstol hubiera renegado de su ciudadanía, cosa que en las cartas nunca viene mencionado, y Hechos parece dar a entender todo lo contrario. Se esperaría un acto de renuncia a su "pasaporte" para declararse ciudadano del mundo o apátrida.

Estos estudios del "Politics Group" demuestran la importancia vital del contexto del imperio romano con su ideología, valores, cultos... para comprender la persona y el mensaje de Pablo. El culto imperial en sí mismo es una faceta importante de este contexto imperial. Cualquiera que sea el origen o derivación de los diversos términos usados para describir el carácter de la dominación de Cristo y sus logros, existen pocas dudas de que en algunos puntos estos términos coinciden con términos usados para expresar la naturaleza del poder imperial romano y la devoción a su culto. Dado el anuncio de la ideología imperial tanto en formas literarias como plásticas -en edificios, estatus, monedas...-, ésa formaba parte del contexto en el que el cristianismo primitivo fue escuchado. Esto implica que los estudiosos del NT deben trabajar con los historiadores y arqueólogos. Una colaboración conjunta ayudará a vislumbrar la importancia de la política dentro de las cartas de Pablo y los problemas de las comunidades. Pablo era un político en la medida que realizaba el arte de lo posible para extender su mensaje en sus comunidades y en el mundo del imperio romano. Pero Pablo no era un político de "profesión" ni buscaba llegar a serlo.

\author{
DAvid Álvarez Cineira \\ Estudio Teológico Agustiniano \\ Valladolid
}

una minoría dentro del imperio, cf. D. Álvarez CineIrA, Pablo ¿un ciudadano romano?, en: Estudio Agustiniano 33 (1998) 455-486. 